4

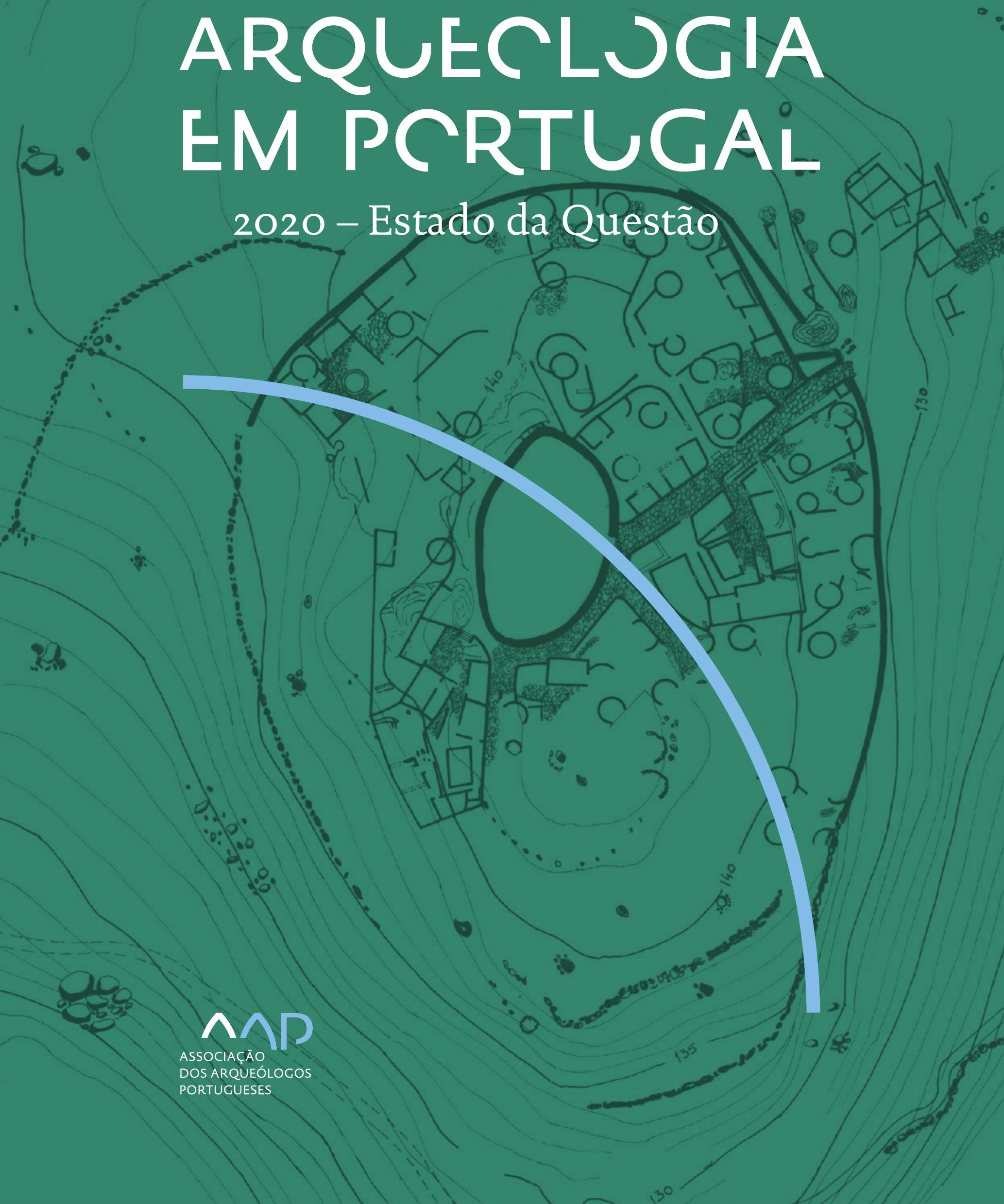


Coordenação editorial: José Morais Arnaud, César Neves e Andrea Martins Design gráfico: Flatland Design

AAP - ISBN: 978-972-9451-89-8

CITCEM - ISBN: 978-989-8970-25-1

Associação dos Arqueólogos Portugueses e CITCEM

Lisboa, 2020

O conteúdo dos artigos é da inteira responsabilidade dos autores. Sendo assim a Associação dos Arqueólogos Portugueses declina qualquer responsabilidade por eventuais equívocos ou questões de ordem ética e legal.

Desenho de capa:

Planta do castro de Monte Mozinho (Museu Municipal de Penafiel).

\section{$\hat{\wedge} \mathrm{P}$}

DOS ARQUEÓLOGOS PORTUGUESES

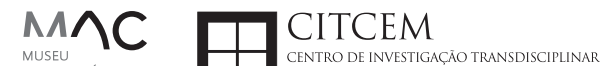
MUSEU
ARQUELLÓGICO
DO CARMO
U.PORTO

FLUP FACULDADE DE LETRAS
UNIVERSIDADE DO PORTO

Apoio

EC para a Ciência 


\section{Índice}

15 Prefácio

José Morais Arnaud

\section{Historiografia e Teoria}

17 Território, comunidade, memória e emoção: a contribuição da história da arqueologia (algumas primeiras e breves reflexões)

Ana Cristina Martins

25 Como descolonizar a arqueologia portuguesa?

Rui Gomes Coelho

41 Arqueologia e Modernidade: uma revisitação pessoal e breve de alguns aspetos da obra homónima de Julian Thomas de 2004

Vítor Oliveira Jorge

57 Dados para a História das Mulheres na Arqueologia portuguesa, dos finais do século XIX aos inícios do século XX: números, nomes e tabelas

Filipa Dimas / Mariana Diniz

73 Retractos da arqueologia portuguesa na imprensa: (in)visibilidades no feminino

Catarina Costeira / Elsa Luís

85 Arqueologia e Arqueólogos no Norte de Portugal Jacinta Bugalhão

101 Vieira Guimarães (1864-1939) e a arqueologia em Tomar: uma abordagem sobre o território e as gentes

João Amendoeira Peixoto / Ana Cristina Martins

115 Os memoráveis? A arqueologia algarvia na imprensa nacional e regional na presente centúria (2001-2019): características, visões do(s) passado(s) e a arqueologia

enquanto marca

Frederico Agosto / João Silva

129 A Evolução da Arqueologia Urbana e a Valorização Patrimonial no Barlavento Algarvio: Os casos de Portimão e Silves

Artur Mateus / Diogo Varandas / Rafael Boavida

\section{Gestão, Valorização e Salvaguarda do Património}

145 O Caderno Reivindicativo e as condições de trabalho em Arqueologia Miguel Rocha / Liliana Matias Carvalho / Regis Barbosa / Mauro Correia / Sara Simões / Jacinta Bugalhão / Sara Brito / Liliana Veríssimo Carvalho / Richard Peace / Pedro Peça / Cézer Santos

155 Os Estudos de Impacte Patrimonial como elemento para uma estratégia sustentável de minimização de impactes no âmbito de reconversões agrícolas Tiago do Pereiro

165 Salvaguarda de Património arqueológico em operações florestais: gestão e sensibilização Filipa Bragança / Gertrudes Zambujo / Sandra Lourenço / Belém Paiva / Carlos Banha / Frederico Tatá Regala / Helena Moura / Jacinta Bugalhão / João Marques / José Correia / Pedro Faria / Samuel Melro

179 Os valores do Património: uma investigação sobre os Sítios Pré-históricos de Arte Rupestre do Vale do Rio Côa e de Siega Verde José Paulo Francisco 
189 Conjugando recursos arqueológicos e naturais para potenciar as visitas ao Geoparque Litoral de Viana do Castelo (Noroeste de Portugal)

Hugo A. Sampaio / Ana M.S. Bettencourt / Susana Marinho / Ricardo Carvalhido

203 Áreas de Potencial Arqueológico na Região do Médio Tejo: Modelo Espacial Preditivo Rita Ferreira Anastácio / Ana Filipa Martins / Luiz Oosterbeek

223 Património Arqueológico e Gestão Territorial: O contributo da Arqueologia para a revisão do PDM de Avis

Ana Cristina Ribeiro

237 A coleção arqueológica do extinto Museu Municipal do Porto - Origens, Percursos e Estudos

Sónia Couto

251 Valpaços - uma nova carta arqueológica

Pedro Pereira / Maria de Fátima Casares Machado

263 Arqueologia na Cidade de Peniche

Adriano Constantino / Luís Rendeiro

273 Arqueologia Urbana: a cidade de Lagos como caso de Estudo Cátia Neto

285 Estratégias de promoção do património cultural subaquático nos Açores. O caso da ilha do Faial

José Luís Neto / José Bettencourt / Luís Borges / Pedro Parreira

297 Carta Arqueológica da Cidade Velha: Uma primeira abordagem

Jaylson Monteiro / Nireide Tavares / Sara da Veiga / Claudino Ramos / Edson Brito /

Carlos Carvalho / Francisco Moreira / Adalberto Tavares

311 Antropologia Virtual: novas metodologias para a análise morfológica e funcional Ricardo Miguel Godinho / Célia Gonçalves

\section{Didáctica da Arqueologia}

327 Como os projetos de Arqueologia podem contribuir para uma comunidade culturalmente mais consciente Alexandra Figueiredo / Claúdio Monteiro / Adolfo Silveira / Ricardo Lopes

337 Educação Patrimonial - Um cidadão esclarecido é um cidadão ativo! Ana Paula Almeida

351 A aproximação da Arqueologia à sala de aula: um caso de estudo no $3^{\circ}$ ciclo do Ensino Básico Luís Serrão Gil

363 Arqueologia 3.o - Pensar e comunicar a Arqueologia para um futuro sustentável Mónica Rolo

377 “Conversa de Arqueólogos" - Divulgar a Arqueologia em tempos de Pandemia Diogo Teixeira Dias

389 Escola Profissional de Arqueologia: desafios e oportunidades Susana Nunes / Dulcineia Pinto / Júlia Silva / Ana Mascarenhas

399 Os Museus de Arqueologia e os Jovens: a oferta educativa para o público adolescente Beatriz Correia Barata / Leonor Medeiros

411 O museu universitário como mediador entre a ciência e a sociedade: o exemplo da secção de arqueologia no Museu de História Natural e da Ciência da Universidade do Porto (MHNC-UP)

Rita Gaspar 
421 Museu de Lanifícios: Real Fábrica de Panos. Atividades no âmbito da Arqueologia Beatriz Correia Barata / Rita Salvado

427 Arqueologia Pública e o caso da localidade da Mata (Torres Novas) Cláudia Manso / Ana Rita Ferreira / Cristiana Ferreira / Vanessa Cardoso Antunes

431 Do sítio arqueológico ao museu: um percurso (também) didático Lídia Fernandes

447 Estão todos convidados para a Festa! E para dançar também... O projecto do Serviço Educativo do Museu Arqueológico do Carmo na $5^{\underline{a}}$ Edição da Festa da Arqueologia Rita Pires dos Santos

459 O “Clã de Carenque”, um projeto didático de arqueologia Eduardo Gonzalez Rocha

469 Mediação cultural: peixe que puxa carroça nas Ruínas Romanas de Troia Inês Vaz Pinto / Ana Patrícia Magalhães / Patrícia Brum / Filipa Santos

481 Didática Arqueológica, experiências do Projeto Mértola Vila Museu Maria de Fátima Palma / Clara Rodrigues / Susana Gómez / Lígia Rafael

\section{Arte Rupestre}

497 Os inventários de arte rupestre em Portugal Mila Simões de Abreu

513 O projeto FIRST-ART - conservação, documentação e gestão das primeiras manifestações de arte rupestre no Sudoeste da Península Ibérica: as grutas do Escoural e Maltravieso Sara Garcês / Hipólito Collado / José Julio García Arranz / Luiz Oosterbeek / António Carlos Silva / Pierluigi Rosina / Hugo Gomes / Anabela Borralheiro Pereira / George Nash / Esmeralda Gomes / Nelson Almeida / Carlos Carpetudo

523 Trabalhos de documentação de arte paleolítica realizados no âmbito do projeto PalæoCôa André Tomás Santos / António Fernando Barbosa / Luís Luís / Marcelo Silvestre / Thierry Aubry

537 Imagens fantasmagóricas, silhuetas elusivas: as figuras humanas na arte do Paleolítico Superior da região do Côa Mário Reis

$55^{1}$ Os motivos zoomórficos representados nas placas de tear de Vila Nova de São Pedro (Azambuja, Portugal) Andrea Martins / César Neves / José M. Arnaud / Mariana Diniz

571 Arte Rupestre do Monte de Góios (Lanhelas, Caminha). Síntese dos resultados dos trabalhos efectuados em 2007-2009 Mário Varela Gomes

599 Gravuras rupestres de barquiformes no Monte de S. Romão, Guimarães, Noroeste de Portugal Daniela Cardoso

613 Círculos segmentados gravados na Bacia do Rio Lima (Noroeste de Portugal): contributos para o seu estudo Diogo Marinho / Ana M.S. Bettencourt / Hugo Aluai Sampaio

631 Equídeos gravados no curso inferior do Rio Mouro, Monção (NW Portugal). Análise preliminar Coutinho, L.M. / Bettencourt, A.M.S / Sampaio, Hugo A.S

645 Paletas na Arte Rupestre do Noroeste de Portugal. Inventário preliminar Bruna Sousa Afonso / Ana M. S. Bettencourt / Hugo A. Sampaio 


\section{Pré-História}

661 O projeto Miño/Minho: balanço de quatro anos de trabalhos arqueológicos Sérgio Monteiro-Rodrigues / João Pedro Cunha-Ribeiro / Eduardo Méndez-Quintas / Carlos Ferreira / Pedro Xavier / José Meireles / Alberto Gomes / Manuel Santonja / Alfredo Pérez-González

677 A ocupação paleolítica da margem esquerda do Baixo Minho: a indústria lítica do sítio de Pedreiras 2 (Monção, Portugal) e a sua integração no contexto regional Carlos Ferreira / João Pedro Cunha-Ribeiro / Sérgio Monteiro-Rodrigues / Eduardo Méndez-Quintas / Pedro Xavier / José Meireles / Alberto Gomes / Manuel Santonja / Alfredo Pérez-González

693 O sítio acheulense do Plistocénico médio da Gruta da Aroeira Joan Daura / Montserrat Sanz / Filipa Rodrigues / Pedro Souto / João Zilhão

703 As sociedades neandertais no Barlavento algarvio: modelos preditivos com recurso aos SIG

Daniela Maio

715 A utilização de quartzo durante o Paleolítico Superior no território dos vales dos rios Vouga e Côa

Cristina Gameiro / Thierry Aubry / Bárbara Costa / Sérgio Gomes / Luís Luís / Carmen Manzano / André Tomás Santos

733 Uma perspetiva diacrónica da ocupação do concheiro do Cabeço da Amoreira (Muge, Portugal) a partir da tecnologia lítica Joana Belmiro / João Cascalheira / Célia Gonçalves

745 Novos dados sobre a Pré-história Antiga no concelho de Palmela. A intervenção arqueológica no sítio do Poceirão I

Michelle Teixeira Santos

757 Problemas em torno de Datas Absolutas Pré-Históricas no Norte do Alentejo Jorge de Oliveira

771 Povoamento pré-histórico nas áreas montanhosas do NO de Portugal: o Abrigo 1 de Vale de Cerdeira Pedro Xavier / José Meireles / Carlos Alves

783 Apreciação do povoamento do Neolítico Inicial na Baixa Bacia do Douro. A Lavra I (Serra da Aboboreira) como caso de estudo Maria de Jesus Sanches

797 O Processo de Neolitização na Plataforma do Mondego: os dados do Sector C do Outeiro dos Castelos de Beijós (Carregal do Sal)

João Carlos de Senna-Martinez / José Manuel Quintã Ventura / Andreia Carvalho / Cíntia Maurício

823 Novos trabalhos na Lapa da Bugalheira (Almonda, Torres Novas) Filipa Rodrigues / Pedro Souto / Artur Ferreira / Alexandre Varanda / Luís Gomes / Helena Gomes / João Zilhão

837 A pedra polida e afeiçoada do sítio do Neolítico médio da Moita do Ourives (Benavente, Portugal)

César Neves

857 Casal do Outeiro (Encarnação, Mafra): novos contributos para o conhecimento do povoamento do Neolítico final na Península de Lisboa.

Cátia Delicado / Carlos Maneira e Costa / Marta Miranda / Ana Catarina Sousa

873 Stresse infantil, morbilidade e mortalidade no sítio arqueológico do Neolítico Final/ Calcolítico ( $4^{\circ}$ e $3^{\circ}$ milénio a.C.) do Monte do Carrascal 2 (Ferreira do Alentejo, Beja) Liliana Matias de Carvalho / Sofia N. Wasterlain 
885 Come together: O Conjunto Megalítico das Motas (Monção, Viana do Castelo) e as expressões Campaniformes do Alto Minho Ana Catarina Basílio / Rui Ramos

899 Trabalhos arqueológicos no sítio Calcolítico da Pedreira do Poio Carla Magalhães / João Muralha / Mário Reis / António Batarda Fernandes

913 O sítio arqueológico de Castanheiro do Vento. Da arquitectura do sítio à arquitectura de um território João Muralha Cardoso

925 Estudo zooarqueológico das faunas do Calcolítico final de Vila Nova de São Pedro (Azambuja, Portugal): Campanhas de 2017 e 2018 Cleia Detry / Ana Catarina Francisco / Mariana Diniz / Andrea Martins / César Neves / José Morais Arnaud

943 As faunas depositadas no Museu Arqueológico do Carmo provenientes de Vila Nova de São Pedro (Azambuja): as campanhas de 1937 a 1967 Ana Catarina Francisco / Cleia Detry / César Neves / Andrea Martins / Mariana Diniz / José Morais Arnaud

959 Análise funcional de material lítico em sílex do castro de Vila Nova de S. Pedro (Azambuja, Portugal): uma primeira abordagem Rafael Lima

971 O recinto da Folha do Ouro 1 (Serpa) no contexto dos recintos de fossos calcolíticos alentejanos

António Carlos Valera / Tiago do Pereiro / Pedro Valério / António M. Monge Soares

\section{Proto-História}

987 Produção de sal marinho na Idade do Bronze do noroeste Português. Alguns dados para uma reflexão

Ana M. S. Bettencourt / Sara Luz / Nuno Oliveira / Pedro P. Simões / Maria Isabel C. Alves / Emílio Abad-Vidal

1001 A estátua-menir do Pedrão ou de São Bartolomeu do Mar (Esposende, noroeste de Portugal) no contexto arqueológico da fachada costeira de entre os rios Neiva e Cávado Ana M. S. Bettencourt / Manuel Santos-Estévez / Pedro Pimenta Simões / Luís Gonçalves

1015 O Castro do Muro (Vandoma/Baltar, Paredes) - notas para uma biografia de ocupação da Idade do Bronze à Idade Média

Maria Antónia D. Silva / Ana M. S. Bettencourt / António Manuel S. P. Silva / Natália Félix

1031 Do Bronze Final à Idade Média - continuidades e hiatos na ocupação de Povoados em Oliveira de Azeméis João Tiago Tavares / Adriaan de Man

1041 As faunas do final da Idade do Bronze no Sul de Portugal: leituras desde o Outeiro do Circo (Beja)

Nelson J. Almeida / Íris Dias / Cleia Detry / Eduardo Porfírio / Miguel Serra

1055 A Espada do Monte das Oliveiras (Serpa) - uma arma do Bronze Pleno do Sudoeste Rui M. G. Monge Soares / Pedro Valério / Mariana Nabais / António M. Monge Soares

1065 São Julião da Branca (Albergaria-a-Velha) - Investigação e valorização de um povoado do Bronze Final

António Manuel S. P. Silva / Paulo A. P. Lemos / Sara Almeida e Silva / Edite Martins de Sá

1083 Do castro de S. João ao Mosteiro de Santa Clara: notícia de uma intervenção arqueológica, em Vila do Conde Rui Pinheiro 
1095 O castro de Ovil (Espinho), um quarto de século de investigação - resultados e questões em aberto

Jorge Fernando Salvador / António Manuel S. P. Silva

1111 O Castro de Salreu (Estarreja), um povoado proto-histórico no litoral do Entre Douro e Vouga

Sara Almeida e Silva / António Manuel S. P. Silva / Paulo A. P. Lemos / Edite Martins de Sá

1127 Castro de Nossa Senhora das Necessidades (Sernancelhe): uma primeira análise artefactual Telma Susana O. Ribeiro

${ }_{1141}$ A cividade de Bagunte. O estado atual da investigação Pedro Brochado de Almeida

1153 Zoomorfos na cerâmica da Idade do Ferro no NW Peninsular: inventário, cronologias e significado Nuno Oliveira / Cristina Seoane

1163 Vasos gregos em Portugal: diferentes maneiras de contar a história do intercâmbio cultural na Idade do Ferro

Daniela Ferreira

1175 Os exotica da necrópole da Idade do Ferro do Olival do Senhor dos Mártires (Alcácer do Sal) no seu contexto regional

Francisco B. Gomes

\section{Antiguidade Clássica e Tardia}

1191 O uso de madeira como combustível no sítio da Quinta de Crestelos (Baixo Sabor): da Idade do Ferro à Romanização Filipe Vaz / João Tereso / Sérgio Simões Pereira / José Sastre / Javier Larrazabal Galarza / Susana Cosme / José António Pereira / Israel Espi

1207 Cultivos de Época Romana no Baixo Sabor: continuidade em tempos de mudança? João Pedro Tereso / Sérgio Simões Pereira / Filipe Santos / Luís Seabra / Filipe Vaz

1221 A casa romana na Hispânia: aplicação dos modelos itálicos nas províncias ibéricas Fernanda Magalhães / Diego Machado / Manuela Martins

1235 As pinturas murais romanas da Rua General Sousa Machado, n. ${ }^{5}$ 1, Chaves José Carvalho

1243 Trás do Castelo (Vale de Mir, Pegarinhos, Alijó) - Uma exploração agrícola romana do Douro

Tony Silvino / Pedro Pereira

1255 A sequência de ocupação no quadrante sudeste de Bracara Augusta: as transformações de uma unidade doméstica Lara Fernandes / Manuela Martins

1263 Os Mosaicos com decoração geométrica e geométrico-vegetalista dos sítios arqueológicos da área do Conuentus Bracaraugustanus. Novas abordagens quanto à conservação, restauro, decoração e datação Maria de Fátima Abraços / Licínia Wrench

1277 “Casa Romana” do Castro de São Domingos (Cristelos, Lousada): Escavação, Estudo e Musealização Paulo André de P. Lemos

1291 A arqueobotânica no Castro de Guifões (Matosinhos, Noroeste de Portugal): O primeiro estudo carpológico

Luís Seabra / Andreia Arezes / Catarina Magalhães / José Varela / João Pedro Tereso 
1305 Um Horreum Augustano na Foz do Douro (Monte do Castelo de Gaia, Vila Nova de Gaia) Rui Ramos

1311 Ponderais romanos na Lusitânia: padrões, formas, materiais e contextos de utilização Diego Barrios Rodríguez

1323 Um almofariz centro-itálico na foz do Mondego

Marco Penajoia

1335 Estruturas romanas de Carnide - Lisboa Luísa Batalha / Mário Monteiro / Guilherme Cardoso

1347 O contexto funerário do sector da "necrópole NO" da Rua das Portas de S. Antão (Lisboa): o espaço, os artefactos, os indivíduos e a sua interconectividade na interpretação do passado Sílvia Loja, José Carlos Quaresma, Nelson Cabaço, Marina Lourenço, Sílvia Casimiro, Rodrigo Banha da Silva, Francisca Alves-Cardoso

${ }_{1361}$ Povoamento em época Romana na Amadora - resultados de um projeto pluridisciplinar Gisela Encarnação / Vanessa Dias

1371 A Arquitectura Residencial em Mirobriga (Santiago do Cacém): contributo a partir de um estudo de caso Filipe Sousa / Catarina Felício

${ }_{1385}$ O fim do ciclo. Saneamento e gestão de resíduos nos edifícios termais de Mirobriga (Santiago do Cacém)

Catarina Felício / Filipe Sousa

1399 Balsa, Topografia e Urbanismo de uma Cidade Portuária Vítor Silva Dias / João Pedro Bernardes / Celso Candeias / Cristina Tété Garcia

1413 No Largo das Mouras Velhas em Faro (2017): novas evidências da necrópole norte de Ossonoba e da sua ocupação medieval Ricardo Costeira da Silva / Paulo Botelho / Fernando Santos / Liliana Nunes

1429 Instrumentos de pesca recuperados numa fábrica de salga em Ossonoba (Faro) Inês Rasteiro / Ricardo Costeira da Silva / Paulo Botelho

1439 A Necrópole Romana do Eirô, Duas Igrejas (Penafiel): intervenção arqueológica de 2016 Laura Sousa / Teresa Soeiro

1457 Ritual, descarte ou afetividade? A presença de Canis lupus familiaris na Necrópole Noroeste de Olisipo (Lisboa)

Beatriz Calapez Santos / Sofia Simões Pereira / Rodrigo Banha da Silva / Sílvia Casimiro / Cleia Detry / Francisca Alves Cardoso

1467 Dinâmicas económicas em Bracara na Antiguidade Tardia Diego Machado / Manuela Martins / Fernanda Magalhães / Natália Botica

1479 Cerâmicas e Vidros da Antiguidade Tardia do Edifício sob a Igreja do Bom Jesus (Vila Nova de Gaia) Joaquim Filipe Ramos

1493 Novos contributos para a topografia histórica de Mértola no período romano e na Antiguidade Tardia Virgílio Lopes

\section{8. Época Medieval}

1511 Cerâmicas islâmicas no Garb setentrional "português": algumas evidências e incógnitas Constança dos Santos / Helena Catarino / Susana Gómez / Maria José Gonçalves / Isabel Inácio / Gonçalo Lopes / Jacinta Bugalhão / Sandra Cavaco / Jaquelina Covaneiro / Isabel Cristina Fernandes / Ana Sofia Gomes 
1525 Contributo para o conhecimento da cosmética islâmica, em Silves, durante a Idade Média Rosa Varela Gomes

1537 Yábura e o seu território - uma análise histórico-arqueológica de Évora entre os séculos VIII-XII José Rui Santos

1547 A encosta sul do Castelo de Palmela - resultados preliminares da escavação arqueológica Luís Filipe Pereira / Michelle Teixeira Santos

1559 A igreja de São Lourenço (Mouraria, Lisboa): um conjunto de silos e de cerâmica medieval islâmica

Andreia Filipa Moreira Rodrigues

1571 O registo material de movimentações populacionais no Médio Tejo, durante os séculos XII-XIII. Dois casos de "sunken featured buildings", nos concelhos de Cartaxo e Torres Novas Marco Liberato / Helena Santos / Nuno Santos

1585 O nordeste transmontano nos alvores da Idade média. Notas para reflexão Ana Maria da Costa Oliveira

1601 Sepulturas escavadas na rocha do Norte de Portugal e do Vale do Douro: primeiros resultados do Projecto SER-NPVD

Mário Jorge Barroca / César Guedes / Andreia Arezes / Ana Maria Oliveira

1619 "Portucalem Castrum Novum" entre o Mediterrâneo e o Atlântico: o estudo dos materiais cerâmicos alto-medievais do arqueossítio da rua de D. Hugo, nํ. 5 (Porto) João Luís Veloso

1627 A Alta Idade Média na fronteira de Lafões: notas preliminares sobre a Arqueologia no Concelho de Vouzela

Manuel Luís Real / Catarina Tente

1641 Um conjunto cerâmico medieval fora de portas: um breve testemunho aveirense Susana Temudo

${ }_{1651}$ Os Lóios do Porto: uma perspetiva integrada no panorama funerário da Baixa Idade Média à Época Moderna em meios urbanos em Portugal

Ana Lema Seabra

1659 O Caminho Português Interior de Santiago como eixo viário na Idade Média Pedro Azevedo

1665 Morfologia Urbana: Um exercício em torno do Castelo de Ourém André Donas-Botto / Jaqueline Pereira

1677 Intervenção arqueológica na Rua Marquês de Pombal/Largo do Espírito Santo (Bucelas, Loures)

Florbela Estêvão / Nathalie Antunes-Ferreira / Dário Ramos Neves / Inês Lisboa

1691 O Cemitério Medieval do Poço do Borratém e a espacialidade funerária na cidade de Lisboa Inês Belém / Vanessa Filipe / Vasco Noronha Vieira / Sónia Ferro / Rodrigo Banha da Silva

1705 Um Espaço Funerário Conventual do séc. XV em Lisboa: o caso do Convento de São Domingos da Cidade Sérgio Pedroso / Sílvia Casimiro / Rodrigo Banha da Silva / Francisca Alves Cardoso

\section{9. Época Moderna e Contemporânea}

1721 Arqueologia Moderna em Portugal: algumas reflexões críticas em torno da quantificação de conjuntos cerâmicos e suas inferências históricas e antropológicas Rodrigo Banha da Silva / André Bargão / Sara da Cruz Ferreira

1733 Faianças de dois contextos entre os finais do século XVI e XVIII do Palácio dos Condes de Penafiel, Lisboa

Martim Lopes / Tomás Mesquita 
1747 Um perfil de consumo do século XVIII na foz do Tejo: O caso do Mercado da Ribeira, Lisboa Sara da Cruz Ferreira / Rodrigo Banha da Silva / André Bargão

1761 Os Cachimbos dos Séculos XVII e XVIII do Palácio Mesquitela e Convento dos Inglesinhos (Lisboa)

Inês Simão / Marina Pinto / João Pimenta / Sara da Cruz Ferreira / André Bargão / Rodrigo Banha da Silva

1775 "Tomar os fumos da erua que chamão em Portugal erua sancta». Estudo de Cachimbos provenientes da Rua do Terreiro do Trigo, Lisboa

Miguel Martins de Sousa / José Pedro Henriques / Vanessa Galiza Filipe

1787 Cachimbos de Barro Caulínitico da Sé da Cidade Velha (República de Cabo Verde)

Rodrigo Banha da Silva / João Pimenta / Clementino Amaro

1801 Algumas considerações sobre espólio não cerâmico recuperado no Largo de Jesus (Lisboa) Carlos Boavida

1815 Adereços de vidro, dos séculos XVI-XVIII, procedentes do antigo Convento de Santana de Lisboa (anéis, braceletes e contas)

Joana Gonçalves / Rosa Varela Gomes / Mário Varela Gomes

1837 Da ostentação, luxo e poder à simplicidade do uso quotidiano: arqueologia e simbologia de joias e adornos da Idade Moderna Portuguesa Jéssica Iglésias

1849 Os amuletos em Portugal - dos objetos às superstições: o coral vermelho Alexandra Vieira

1865 Cerâmicas de Vila Franca de Xira nos séculos XV e XVI Eva Pires

1879 «Não passa por teu o que me pertence». Marcas de individualização associadas a faianças do Convento de Nossa Senhora de Aracoeli, Alcácer do Sal Catarina Parreira / Íris Fragoso / Miguel Martins de Sousa

1891 Cerâmica de Leiria: alguns focos de produção

Jaqueline Pereira / André Donas-Botto

1901 Os Fornos na Rua da Biquinha, em Óbidos Hugo Silva / Filipe Oliveira

1909 A casa de Pêro Fernandes, contador dos contos de D. Manuel I: o sítio arqueológico da Silha do Alferes, Seixal (século XVI) Mariana Nunes Ferreira

1921 O Alto da Vigia (Sintra) e a vigilância e defesa da costa Alexandre Gonçalves / Sandra Santos

1937 O contexto da torre sineira da Igreja de Santa Maria de Loures Paulo Calaveira / Martim Lopes

1949 A Necrópole do Hospital Militar do Castelo de São Jorge e as práticas funerárias na Lisboa de Época Moderna Susana Henriques / Liliana Matias de Carvalho / Ana Amarante / Sofia N. Wasterlain

1963 SAND - Sarilhos Grandes Entre dois Mundos: o adro da Igreja e a Paleobiologia dos ossos humanos recuperados

Paula Alves Pereira / Roger Lee Jesus / Bruno M. Magalhães

1975 Expansão urbana da vila de Cascais no século XVII e XVIII: a intervenção arqueológica na Rua da Vitória no 15 a 17

Tiago Pereira / Vanessa Filipe

1987 Novos dados para o conhecimento do Urbanismo de Faro em época Moderna Ana Rosa 
1995 Um exemplo de Arqueologia Urbana em Alcoutim: o Antigo Edifício dos CTT Marco Fernandes / Marta Dias / Alexandra Gradim / Virgílio Lopes / Susana Gómez Martínez

2007 Palácio dos Ferrazes (Rua das Flores/Rua da Vitória, Porto): a cocheira de Domingos Oliveira Maia

Francisco Raimundo

2021 As muitas vidas de um edifício urbano: História, Arqueologia e Antropologia no antigo Recreatório Paroquial de Penafiel Helena Bernardo / Jorge Sampaio / Marta Borges

2035 O convento de Nossa Senhora da Esperança de Ponta Delgada: o contributo da arqueologia para o conhecimento de um monumento identitário João Gonçalves Araújo / N’Zinga Oliveira

2047 Arqueologia na ilha do Corvo... em busca da capela de Nossa Senhora do Rosário Tânia Manuel Casimiro / José Luís Neto / Luís Borges / Pedro Parreira

2059 Perdidos à vista da Costa. Trabalhos arqueológicos subaquáticos na Barra do Tejo Jorge Freire / José Bettencourt / Augusto Salgado

2071 Arqueologia marítima em Cabo Verde: enquadramento e primeiros resultados do projecto CONCHA

José Bettencourt / Adilson Dias / Carlos Lima / Christelle Chouzenoux / Cristóvão Fonseca / Dúnia Pereira / Gonçalo Lopes / Inês Coelho / Jaylson Monteiro / José Lima / Maria Eugénia Alves / Patrícia Carvalho / Tiago Silva

2085 Trabalhos arqueológicos na Cidade Velha (Ribeira Grande de Santiago, Cabo Verde): reflexões sobre um projecto de investigação e divulgação patrimonial André Teixeira / Jaylson Monteiro / Mariana Mateus / Nireide Tavares / Cristovão Fonseca / Gonçalo C. Lopes / Joana Bento Torres / Dúnia Pereira / André Bargão / Aurélie Mayer / Bruno Zélie / Carlos Lima / Christelle Chouzenoux / Inês Henriques / Inês Pinto Coelho / José Lima / Patrícia Carvalho / Tiago Silva

2103 A antiga fortificação de Quelba / Khor Kalba (E.A.U.). Resultados de quatro campanhas de escavações, problemáticas e perspectivas futuras Rui Carita / Rosa Varela Gomes / Mário Varela Gomes / Kamyar Kamyad

2123 Colónias para homens novos: arqueologia da colonização agrária fascista no noroeste ibérico Xurxo Ayán Vila / José Mạ . Señorán Martín 


\title{
DIDÁTICA ARQUEOLÓGICA, EXPERIÊNCIAS DO PROJETO MÉRTOLA VILA MUSEU
}

\author{
Maria de Fátima Palma ${ }^{1}$, Clara Rodrigues $^{2}$, Susana Gómez ${ }^{3}$, Lígia Rafael ${ }^{4}$
}

\begin{abstract}
RESUMO
Em 2018, o projeto Mértola Vila Museu, uma experiência única de preservação e divulgação patrimonial, completou 40 anos de existência. Baseado no estudo, pesquisa, conservação, salvaguarda e divulgação, este projeto tem sido experienciado das mais diversas formas, com resultados visíveis em termos científicos e com uma importante ligação à comunidade local, com o objetivo de sensibilizar para a preservação do património histórico e arqueológico. Neste texto abordamos a didática arqueológica através da experiência de Mértola, apresentando as práticas e as abordagens que têm no património o elemento estruturante do desenvolvimento local e do envolvimento da comunidade. São explicitados os pressupostos do projeto e as experiências do Campo Arqueológico de Mértola e do Museu de Mértola levadas a cabo em sítios arqueológicos, em contacto direto com a comunidade escolar e local, com o objetivo de criar laços identitários e de pertença.
\end{abstract}

Palavras-chave: Educação patrimonial, Didática, Mértola, Arqueologia cidadã.

\begin{abstract}
In 2018 the Mértola Vila Museu project, an unique experience of preservation and heritage diffusion, completed 40 years of existence. Based on study, research, conservation, safeguard and exposure, this project has been experienced in the most diverse ways with visible scientifical output and with an important connection with the local community, all this with the goal of educating and sensitizing for the preservation of historic and arqueological heritage. In this text we approach the arqueological didactic through the experience of Mértola, presenting the practices and approaches that have in heritage the structural element for the local development and community engagement. The premises of the project and of the experiences of the Campo Arqueológico of Mértola and the Museum of Mértola are clarified in direct contact with the school and local community, with the aim of creating identitary bonds and a sense of belonging.
\end{abstract}

Keywords: Heritage Education, Didactic, Mértola, Identitary bonds.

\section{INTRODUÇÃO}

O Projeto "Mértola Vila Museu" nasce de uma experiência científica, museográfica e pedagógica que não se pode desassociar de um programa estruturante, com um cariz marcadamente político, num interior empobrecido e sobretudo despovoado. O trabalho científico desenvolvido em torno do património local levou a uma redescoberta da história do lugar, dig- nificando os seus espaços e contribuindo para a criação de espaços museográficos e consequentemente um poderoso fator de desenvolvimento cultural e económico (Torres, 1989; Torres, 1993; Rafael, 2010; Rafael e Palma, 2013; Gómez, Rafael e Torres, 2016; Gómez, 2016; Palma e Rodrigues, 2019).

Muitas são as atividades pensadas e desenvolvidas no âmbito deste projeto, num contacto estreito entre instituições parceiras e que trabalham em prol

\footnotetext{
1. FCT/CAM/CEAACP/Universidade de Granada; tuchapalma @hotmail.com

2.CAM/CEAACP; clara.r.guerreiro@hotmail.com

3. Universidade de Évora/CAM/CEAACP; susanagomez@sapo.pt

4. Câmara Municipal de Mértola; ligiarafael@cm-mertola.pt
} 
do desenvolvimento local, mas que também pretendem estar presentes na comunidade, tentando incutir um sentimento de pertença sobre o património que é seu. Desta forma, através da educação patrimonial direcionada a diversas faixas etárias, temos vindo a realizar um trabalho que tenta incutir um sentimento de pertença e apropriação do seu património através de diversas experiências de arqueologia participativa. Apesar de não existir um serviço educativo estruturado, uma pequena equipa de técnicos das mais diversas áreas das duas instituições, tem vindo a pensar e a desenvolver atividades que pretendem consciencializar e sensibilizar para a preservação do património local fazendo dos alunos e demais participantes nas atividades agentes da salvaguarda do seu património.

\section{O CAMPO ARQUEOLÓGICO DE MÉRTOLA}

Em Mértola os trabalhos arqueológicos principiaram no final dos anos setenta do século XX, com uma continuidade regular até ao presente. Desde o primeiro momento, iniciaram-se as recolhas de materiais arqueológicos, etnográficos e religiosos por uma equipa multidisciplinar, liderada pelo Professor Cláudio Torres, que se instalou em Mértola e começou a desenvolver em continuidade trabalhos de arqueologia e levantamento do património histórico, antropológico e artístico, sempre com o apoio da Câmara Municipal de Mértola (CMM). Neste âmbito, não podemos deixar de referir a figura que impulsionou o início do projeto, António Serrão Martins, o primeiro Presidente da Câmara eleito democraticamente e que trouxe a Mértola os seus professores da Faculdade de Letras da Universidade de Lisboa, Cláudio Torres, António Borges Coelho e José Luís de Matos.

Os primeiros anos de trabalhos de arqueologia e património foram intensos e desenvolvidos no âmbito da Associação para a Defesa do Património de Mértola (ADPM), que posteriormente daria origem ao Campo Arqueológico de Mértola (CAM), legalmente constituído como uma associação cultural e científica sem fins lucrativos, de utilidade pública, com os objetivos de fomentar o levantamento, estudo e pesquisa do património da região de Mértola e a sua conservação e salvaguarda, podendo, para tal, cooperar com entidades públicas ou privadas em ações científicas ou de promoção cultural e social.
Ao longo de mais de 40 anos sucederam-se projetos de investigação que levaram, em 2003 à constituição de uma unidade de investigação reconhecida pelo Ministério de Ciência e Tecnologia e em 2008, à união com o agora denominado Centro de Estudos em Arqueologia e Ciências do Património (CEAA$\mathrm{CP}$ ), com polos nas Universidades de Coimbra, do Algarve e em Mértola. A parceria com diversas Universidades e outras instituições de ensino deu lugar a cursos de Formação Profissional (em colaboração com EPBJC, ALSUD, IEFP, ADPM), mestrados (em colaboração com as Universidades do Algarve, Évora e Lisboa), estágios no âmbito de pós-graduações (Universidades de Granada, Sevilha ou Huelva), cursos livres e atividades de divulgação e educação patrimonial com a comunidade.

Muitos dos projetos de investigação eram simultaneamente projetos de valorização patrimonial e tiveram como corolário a divulgação para o público geral através do vasto programa editorial do CAM e da musealização de sítios ou em forma de exposições temporárias ou permanentes. Ao longo destas 4 décadas de investigação e divulgação patrimonial, resultado da necessidade de apresentar e partilhar conhecimento, nasceram, em 2004, os diversos núcleos museológicos do Museu de Mértola (MM), 14 na atualidade, 11 instalados no Centro Histórico e arrabalde da Vila de Mértola e os restantes nas localidades de Mosteiro, Mina de S. Domingos e Alcaria dos Javazes.

\section{MUSEU DE MÉRTOLA - MISSÃO E OBJETIVOS}

Para o visitante a arqueologia ganha vida através dos objetos e dos cenários criados nas vitrinas dos museus, onde a informação histórica e arqueológica se transforma numa linguagem simples, que pretende transmitir conhecimentos e enriquecer, a nível pessoal e cultural, os seus públicos. Um museu não é só um local onde se mostram objetos e se preservam as memórias de um espaço e de um tempo. É, acima de tudo, um importante elo de ligação com as pessoas e representa a sua identidade coletiva.

O caso de Mértola é referência nacional pela forma como estuda, analisa e apresenta o Património, numa abordagem global que se estende ao território e às pessoas, estas últimas, principais agentes de conhecimento, transformação e divulgação. A apresentação de estruturas arqueológicas in situ e inte- 
gradas em museus é inovadora e interessante como forma de exposição, mas também como meio para manter a autenticidade histórica de cada local, ajudando num melhor entendimento do território e da sua ocupação humana ao longo dos tempos.

O Museu de Mértola não se encerra nos seus 14 núcleos museológicos temáticos. Trata-se de um grande museu disseminado pelo território, com espaços privilegiados de análise e interpretação do espaço, do tempo e das suas gentes. A sua Missão é estudar, inventariar, conservar, documentar e divulgar o seu acervo, e apoiar e colaborar na salvaguarda, estudo e divulgação do património cultural, material e imaterial, do concelho de Mértola, através da colaboração com outros museus e instituições nacionais ou estrangeiras.

Esta unidade museológica tem como objetivos principais:

a) Estudar, inventariar, conservar e divulgar as coleções que integram o seu acervo;

b) Valorizar as coleções entendidas como testemunho da cultura material e da identidade das gentes de Mértola ao longo dos tempos;

c) Enquanto Museu da Rede Portuguesa de Museus, integrar no seu acervo todos os bens procedentes de intervenções arqueológicas ou de recolhas realizadas no concelho promovendo o seu inventário, acondicionamento, conservação e estudo;

d) Apoiar e colaborar na salvaguarda, estudo e divulgação do património cultural, material eimaterial, do concelho de Mértola no âmbito nacional e internacional;

e) Promover e desenvolver estudos e investigação que contribua para o conhecimento da História Local;

f) Desenvolver estratégias de trabalho que permitam captar novos públicos e fortalecer os laços identitários e de pertença da comunidade local;

g) Estabelecer parcerias e colaborações com instituições locais, nacionais e estrangeiras tendo em vista o estudo, a preservação, a valorização, a divulgação e a fruição do património local.

h) Apoiar a criação, organização e consolidação de novos núcleos museológicos ou museus a serem criados no concelho de Mértola, muito especificamente aqueles criados pela Autarquia, ajudando a promover e difundir as boas práticas inerentes à museologia, sempre com uma preocupação social e pedagógica e tendo em conta o desenvolvimento de um turismo cultural de qualidade.

I) Participar em projetos integrado em redes de âmbito local, regional, nacional e internacional como é o caso da Rede de Museus Rurais do Sul, da Rede de Museus do Baixo Alentejo, da Rede de Recursos Museológicos do Alentejo e da Rede Portuguesa de Museus.

\section{EDUCAÇÃO PATRIMONIAL: EXPERIÊNCIAS PARTILHADAS NA DIDÁTICA ARQUEOLÓGICA E PATRIMONIAL EM MÉRTOLA}

Educação Patrimonial - Heritage Education - é um conceito antigo que pretende explicitar a transmissão do conhecimento histórico de forma a criar públicos informados e participativos. Em Portugal, este conceito começou a ser utilizado durante o Estado Novo, como forma de valorização e de exaltação de uma memória nacional. Após o 25 de Abril de 1974, o conceito sofreu alterações relacionadas com novos ideais e novas formas de entender a importância do Património e da Cultura na formação dos indivíduos o que resultou na constituição de associações de defesa do património por todo o país (Custódio, 200o, p.10) e na necessidade crescente de uma educação patrimonial como forma de salvaguarda e valorização do património. Na década de 90 continuaram e desenvolveram-se múltiplos mecanismos que incentivaram o desenvolvimento da temática da educação para o património, no mesmo âmbito da educação ambiental, mas em menor escala e com menor incidência.

A Lei de Bases do Património Cultural, de 8 de Setembro de 2001, apresenta uma noção abrangente do conceito património, reflete as preocupações surgidas na década anterior, mas está ainda aquém de uma verdadeira preocupação com a educação patrimonial. Como refere Jorge Custódio, "reconhecem-se como deveres do Estado, das Regiões Autónomas e das Autarquias locais o conhecimento, o estudo, a proteção, a valorização e a divulgação do património cultural, ainda sem menção expressa e inequívoca ao dever de uma educação dirigida e orientada para a formação de uma consciência patrimonial, em todas as classes e para todos os cidadãos" (Custódio, 2000, p. 10).

A Educação Patrimonial utiliza o património como fonte para a construção do saber histórico de uma forma pedagógica e didática. No caso de Mértola alia 
a investigação ao impacto afetivo na população local, com repercussões na preocupação com o seu património e na curiosidade de o conhecer, adquirindo uma dimensão cívica, que começa nos mais jovens (3 a 1o anos) com o objetivo de incutir respeito e criar laços identitários com o património que é pertença de todos (Palma e Rodrigues, 2019). Em Mértola, desde o início do Projeto em 1979, que a Educação Patrimonial tem sido uma constante. Mesmo não estando debaixo deste "chapéu", sempre houve a consciência de que era necessário o envolvimento da comunidade local no processo que se iniciava, de resgaste do passado e sobretudo da História de uma pequena Vila do interior alentejano, capaz de dar a conhecer à população, de uma forma simples e intuitiva, o seu património. Isto é, formar cidadãos conscientes dos seus bens e dos recursos, da sua terra, também permite que estes os relacionem com os outros bens culturais do país e do mundo. Trata-se de usar os diferentes patrimónios com o objetivo de educar para a identificação, a proteção, a valorização e a "apropriação" do Património Cultural como "coisa" de todos.

Desde o seu início que o CAM, e mais tarde o MM, pretendem ser presenças assíduas na comunidade local, de uma forma direta, tentando educar para a valorização e preservação do património. Durante muitos anos o trabalho com as escolas foi sendo feito de forma não muito assídua, só em situações pontuais como visitas, alguns trabalhos de ATL e atividades temáticas feitas de forma muito esporádica. Esta realidade veio a alterar-se a partir de 2010, altura em que o CAM, em parceria com o MM, começou a realizar, de forma sistemática, várias atividades temáticas de educação para o património, inseridas num programa geral, destinados a alunos do Pré-escolar ( 3 a 6 anos) e 1ํㅡㄹ Ciclo (6 a 1o anos) do Agrupamento de Escolas de Mértola. As abordagens tentam ser diversificadas e alternadas para que as crianças possam ter, durante o seu percurso escolar, a perceção do património existente, as diferentes culturas que deixaram vestígios, e o conhecimento dos processos que os materiais arqueológicos sofrem desde a sua descoberta até serem expostos no Museu. Com estas atividades pretendemos criar raízes identitárias com o vasto e diversificado património existente no concelho, educando para a preservação e valorização do património local. As nossas atividades encontram-se, sobretudo, dentro do contexto da educação não formal, isto é, educação nos museus, associações locais, monumentos, sítios, centros culturais, centros históricos, entre outros e educação informal através de ações de formação para docentes e profissionais da área. No contexto de educação formal, promovida através das escolas participamos na forma de visitas guiadas, aulas temáticas e palestras.

Apresentamos algumas das experiências partilhadas na didática arqueológica e patrimonial desenvolvidas pelo CAM e MM, com incidência nos últimos anos:

- Escavações: Muito do trabalho desenvolvido ao longo dos últimos quarenta anos foi materializado por jovens estudantes de Mértola e de fora que, trocaram o seu tempo livre por trabalho voluntário na descoberta da história do passado desta Vila. Os trabalhos de escavação na Alcáçova e Encosta do Castelo, o sítio primordial das intervenções arqueológicas em Mértola, foi continuamente intervencionado, pondo a descoberto os níveis da Necrópole Medieval/Moderna, Criptopórtico, os Batistérios, os mosaicos, o Bairro Islâmico, através da leitura das sucessivas camadas de terra que guardavam as memórias das civilizações passadas. Pretende-se um maior conhecimento desta zona e das diversas estruturas que tem vindo a surgir, sempre num ambiente de aprendizagem e partilha entre os jovens investigadores vindos de fora, os jovens locais e a equipa de investigação (Palma, 2019) (Figura 1).

- Ocupação de Tempos Livres: Este é um programa do Instituto Português do Desporto e Juventude (IPDJ) que proporciona aos jovens experiências em contexto de aprendizagem não-formal ou em contextos ativos de trabalho e pretende desenvolver capacidades e competências pessoais e sociais. No CAM este tipo de atividades foi sempre uma prática, sobretudo nos finais dos anos 90 e inícios de 2000, com a forte participação de jovens locais, que durante as suas férias de verão, participavam nas escavações arqueológicas e em toda a dinâmica a elas associada.

- Campos de Trabalho Internacionais: Este tipo de campo de trabalho foi dinamizado pela equipa do CAM, como apoio do IPDJ, visando a promoção do intercâmbio de jovens (portugue- 
ses e de outros países europeus) e da troca de experiências interculturais, ao mesmo tempo que se divulgava o trabalho arqueológico e patrimonial realizado em Mértola. Os jovens praticaram trabalhos de escavação arqueológica na Alcáçova do Castelo de Mértola e tiveram contacto com todas as metodologias realizadas durante todo o processo da escavação ao Museu, obtidas através de processos educativos não formais. Todos os trabalhos têm acompanhamento técnico especializado nas várias áreas de intervenção arqueológica.

- Dinamização de recriações históricas: Numa dinâmica de divulgação da história local, que estava a ser descoberta através da arqueologia, nos anos 9o, diversas instituições (CAM, CMM, MM, ADPM e Agrupamento de Escolas) estimularam atividades de recriação de ambientes medievais, feiras, chegada de reis através do rio, envolvendo toda a comunidade escolar, a população e as instituições locais. O CAM contribuiu com a documentação histórico-arqueológica como base para uma melhor caracterização dos ambientes e figurinos. Após um trabalho com as escolas e professores, durante o ano letivo, os alunos e professores tornaram-se figurantes destas recriações, onde as vestes e os adereços utilizados foram realizados durante as aulas de trabalhos manuais. Dinamizaram-se diversas atividades, centradas no núcleo dentro das muralhas, a denominada Vila Velha, com o foco no Castelo, na praça Luís de Camões ou no Rio Guadiana, a grande via comercial e de comunicação em tempos idos. Atualmente, promovida pelo grupo de História do Agrupamentos de Escolas, realiza-se anualmente um Mercado Rural do início do século XX. As crianças, vestidas à época, recriam um antigo mercado, onde não faltam os produtos tradicionais da época e da região, vendidos a granel. Há um envolvimento da comunidade através dos professores, alunos, famílias e da população local.

- Exposições: Uma das principais componentes do Projeto Mértola Vila Museu é a divulgação, e durante estas últimas quatro décadas foram promovidas com regularidade algumas exposições temporárias e itinerantes, sempre que possível acompanhadas dos seus respetivos catálogos e com itinerâncias em Portugal e no estrangeiro. A primeira exposição temporária realizou-se em 1982, na Igreja da Misericórdia, e teve como principal objetivo dar a conhecer os resultados das intervenções arqueológicas realizadas na Alcáçova, o levantamento e recolha patrimonial realizado em todo o concelho de Mértola. Foi também um importante momento de apresentação de todo o processo de recolha e tratamento de materiais, de valorização e reconhecimento do envolvimento dos diversos técnicos, onde se incluíam muitos jovens de Mértola. Ao longo dos tempos foram sendo trabalhadas, no âmbito de projetos de investigação, algumas exposições com realce para as seguintes: "Cerâmica Islâmica Portuguesa" (1987), "O Islão entre Tejo e Odiana” (1998), "Mértola. O último Porto do Mediterrâneo" (2005), "Mértola e Niebla en la confluência de dois territórios" (2006), "Os signos do quotidiano - gestos, marcas e símbolos no Al-Ândalus" (2011), "O Sudoeste Peninsular entre Roma e o Islão" (2014), "No extremo do Al-Ândalus - Mértola e o Guadiana” (2014), entre outras.

- Conferências e Congressos: A divulgação do trabalho desenvolvido assenta sobretudo na divulgação em Congressos, Encontros científicos e em revistas da especialidade. Contudo, é frequente a realização de conferências para o público local, Ciclos de Conversas, tertúlias entre outros.

- Cursos Livres: Esta tipologia de cursos tem como objetivo formar e diversificar o conhecimento intrínseco à Arqueologia e ao Património. Os destinatários destes cursos de livre configuração são sobretudo estudantes de Arqueologia e profissionais da área do Património que sentem a necessidade de aprofundar conhecimentos em áreas pouco desenvolvidas na sua formação profissional e académica. Estão também disponíveis para o público em geral.

- Universidade Sénior de Mértola: Em colaboração com a Universidade Sénior têm sido realizadas algumas ações que visam sensibilizar e dar a conhecer o trabalho que se faz em Mértola relacionado com o património e com a divulgação patrimonial. Neste âmbito têm sido realizadas 
nos diversos polos da Universidade (por todo o concelho) sessões de sensibilização, visitas guiadas aos núcleos museológicos e aos gabinetes do Museu de Mértola, ateliers de conservação de cerâmica, de artes plásticas, de antropologia (Figura 2) e o desenvolvimento de conteúdos para exposições temáticas. Como é o caso da que se irá realizar no Núcleo Museológico de Alcaria dos Javazes com o tema "No tempo em que não havia torneiras”, que alia a temática do património à da educação ambiental.

- “Arqueologia para todos": Pensada numa ótica de Ciência Cidadã, esta atividade tem como objetivo divulgar uma arqueologia participativa junto dos cidadãos locais, das mais diversas faixas etárias, mas também dos visitantes, turistas e voluntários envolvendo-os de forma ativa e dinâmica em experiências comunitárias e participativas com o objetivo de incutir sentimentos identitários e de pertença. Na ação Museu Vivo, um programa diversificado, pretende levar o público a conhecer as descobertas da investigação e as peças dos museus nos locais mais frequentados pela população (Centro de Saúde, Bancos, Repartições Municipais e das Finanças, Juntas de Freguesia, entre outros). As Oficinas de Ciência Cidadã, dirigidas às famílias, convidam-nas à participação em ateliers temáticos. O Campo de trabalho em arqueologia inicia os jovens na aprendizagem e nas dinâmicas da prática arqueológica (Figura 3).

- Ações de Formação com professores: Tendo em conta a enorme riqueza patrimonial de Mértola, com grande expressão nas temáticas e conteúdos dos núcleos do Museu de Mértola, e as possibilidades que esta realidade confere enquanto instrumento de trabalho e de abordagem dos diversos períodos históricos, o contacto direto com os professores do Agrupamento de Escolas de Mértola é essencial. Neste âmbito realizam-se apresentações e visitas guiadas com o objetivo de sensibilizar os professores para as temáticas e conteúdos dos núcleos museológicos realçando as suas potencialidades e abrindo portas a parcerias e colaborações que permitam enriquecer os currículos dos diversos níveis de ensino.
- Visitas Guiadas a grupos locais: Cumprido com os objetivos do CAM e Museu de Mértola e com o privilégio dado à comunicação com a comunidade local, realizam-se ações de sensibilização e divulgação junto de diversos públicos locais, que têm nas visitas guiadas aos núcleos museológicos o seu principal ponto de interesse. Estas visitas constituem momentos interessantes de partilha e convívio que permitem a criação de laços e a disseminação de informação, estando de uma forma genérica também relacionadas com instituições locais como o Campo Arqueológico de Mértola, a Associação de Defesa do Património de Mértola, a Escola Profissional ALSUD, o Agrupamento de Escolas de Mértola, as Juntas de Freguesia, a Santa Casa da Misericórdia, entre muitas outras.

- Projetos Transfronteiriços: "Arqueocultura - Salvaguarda e Valorização dos Recursos Arqueológicos, Patrimoniais e Culturais", promovido pela Câmara Municipal de Mértola, a Câmara Municipal de Moura e o Ayuntamiento de Aroche (Huelva-Espanha) e financiado pelo programa comunitário INTERREG IIIA (2006-2008), tinha numa das suas vertentes o intercâmbio e a dinamização de atividades entre jovens dos três concelhos, por forma a conhecerem o património das três localidades, numa troca de experiências transfronteiriças. Do projeto resultou o desenvolvimento de um Jogo de tabuleiro sobre o património das três localidades, visitas guiadas aos locais de interesse patrimonial das três localidades e outras intervenções no âmbito da preservação e valorização do Património.

Práticas Educativas com a comunidade escolar do Concelho de Mértola:

- "A Minha Escola tem um Museu”: Pretende dar a conhecer o Núcleo Museológico da Ermida e Necrópole de S. Sebastião, que se localiza dentro do recinto escolar da Escola EB2/3 ES de Mértola. Ao contrário de outras escolas que adotam um Museu, em Mértola a escola tem um Museu in situ. Assim, no Dia da Escola, dia 20 de Janeiro, realizam-se várias atividades, que pretendem dar a conhecer à comunidade escolar o Núcleo Museológico da Ermida e Necrópole 
de São Sebastião. Com a mais-valia de complementar os conteúdos de algumas disciplinas, dá-se a conhecer o trabalho que é realizado desde a escavação até à chegada dos objetos ao Museu. Demonstra-se, também, como se realiza todo o processo de escavação, podendo os alunos participar numa escavação fictícia. Por outro lado é relembrado aos alunos, professores e funcionários a importância da salvaguarda do património, sobretudo aquele que têm dentro da Escola.

- "O Património da Minha Vila": Esta atividade decorre nas diversas escolas do concelho de Mértola, levando até às crianças a importância da preservação do Património local. Pretendemos dar a conhecer os distintos meios de divulgação do património, enunciar e distinguir as diferentes definições e tipos de património existentes na Vila de Mértola e seu concelho (arqueológico, arquitetónico, natural e oral), como o podemos preservar e valorizar, criando laços identitários com o mesmo (Figura 4).

- "Vamos Escavar": Numa caixa arqueológica com estratigrafia e artefactos arqueológicos de diversas épocas, crianças e jovens transformam-se em pequenos arqueólogos utilizando as ferramentas e técnicas da profissão. A atividade completa-se com as fases de registo arqueológico (caderno de campo, desenho, fotografia), criando momentos de descoberta, disciplina e metodologia. Os alunos têm a oportunidade de contatar com diferentes práticas do trabalho arqueológico e sentir o prazer da descoberta inerente a esta profissão.

- "Vamos ao Laboratório de Materiais não cerâmicos": Visita ao Laboratório de Conservação de Metais Arqueológicos, observação de objetos através da lupa binocular e identificação de materiais. Reconhecimento do trabalho do conservador restaurador através da utilização de materiais pedagógicos (jogos, puzzles, etc.).

- "Conservação e restauro de cerâmica arqueológica": Sendo os fragmentos de cerâmica os mais abundantes numa escavação, e tendo os alunos passado pelo Atelier de Escavação, é importante que reconheçam as formas de os restaurar e conservar. Desta forma, dá-se a conhecer aplicando na prática, as técnicas de conservação e restauro de cerâmica. Pretende-se que as crianças apreendam o processo que uma peça cerâmica passa desde a sua descoberta na escavação até à sua exposição no Museu (Figura 5).

- "Identificar os Ossos Humanos": Identificação dos ossos do corpo humano através do recurso a esqueletos encontrados nas Necrópoles da Antiguidade Tardia de Mértola, bem como aprofundar os conhecimentos de diversas formas de enterramento consoante os períodos históricos. Pretende-se também um reconhecimento e distinção do trabalho do Antropólogo e do Arqueólogo, com o objetivo de proporcionar às crianças do $4^{\circ}$ ano a aprendizagem, de forma lúdica, do corpo humano, indo ao encontro do plano curricular para este ano.

- “A Casa Islâmica”: Visita e dinamização da atividade na réplica da Casa Islâmica, mostrando aos alunos as diferenças e semelhanças das casas atuais e de uma casa do período islâmico, identificando cada compartimento, os objetos utilizados e as formas de construir. De seguida realiza-se uma visita dinamizada às estruturas arqueológicas das casas islâmicas que se encontram escavadas na Alcáçova de Mértola.

- "Atividades Tradicionais: A Tecelagem": A atividade decorre na Oficina de Tecelagem onde os alunos podem ter contato com parte final do processo de transformação da lã, tendo oportunidade de tocar na lã e nos seus derivados. É possível ver a tecedeira no tear, ver a roca a fiar e tocar em diferentes texturas da lã. A atividade complementa-se com uma parte prática em que os alunos têm a oportunidade de fazer o trabalho num pequeno tear e realizar diversas atividades lúdicas que complementam e fortalecem os seus conhecimentos sobre este saber-fazer tradicional cada vez menos usual.

- "Visitas Guiadas ao Núcleos Museológicos": Esta atividade realiza-se durante o ano escolar e consiste em dar a conhecer aos alunos os diversos núcleos museológicos do Museu de Mértola, tentando que a visita complemente os planos curriculares das disciplinas, sobretudo de História e Estudo do Meio. 
- “O que contam os objetos?”: O objetivo desta atividade é dar a conhecer os objetos arqueológicos e etnográficos, sensibilizando os participantes para a história que cada objeto pode conter, sendo ele antigo ou não. Pretende-se a salvaguarda e conservação do património móvel.

- "Os árabes de Martulah": Esta atividade consiste em dar a conhecer aos alunos a presença árabe em Mértola e a importância que esta Vila teve durante os quase seis séculos da sua permanência, em que foi uma importante cidade do mediterrâneo. Integrada no Festival Islâmico de Mértola 2019, esta atividade teve vários momentos durante o ano letivo, tal como uma série de ações, como uma primeira sessão explicativa de quem eram os árabes e os vestígios que ainda existem em Mértola, seguido de uma visita ao núcleo museológico do Museu de Mértola Museu de Arte Islâmica e à réplica da Casa islâmica. Os alunos foram convidados a recriarem os seus trajes de influência árabe durante o ano escolar, para no primeiro dia do festival, visitarem o souk, vestidos com os trajes, sentindo-se integrados em todo o ambiente da festa, culminando numa grande atividade com várias ações lúdicas, como por exemplo, a pintura de desenhos árabes, o que comiam os árabes, palavras árabes, a recriação dos espaços de uma casa, entre outras (Figura 6).

- “Os romanos de Myrtilis": Esta atividade surge na sequência das grandes descobertas arqueológicas realizadas no verão de 2017, na Casa Cor de Rosa. A monumentalidade das estruturas e da riqueza das estátuas postas a descoberto despertou na comunidade local alguma curiosidade sobre estas descobertas, mas também sobre os Romanos que habitaram Mértola e a importância da cidade nessa altura. Sugerimos que fosse realizado o "Dia do Romano de Myrtilis", onde as crianças desfilaram com os seus fatos de romanos ao mesmo tempo que se realizam outras atividades. Foram recriados pequenos espaços de época romana (casa, templo, ruas...) e das vivências que os romanos tinham em Mértola e a importância que a cidade teve durante este período histórico (ex. cunhagem de moeda). As crianças realizaram um desfile para mostrar as suas vestes de romanos (imperadores, guerreiros, imperatrizes, togados...) (Figura 7). Durante toda a atividade a população e turistas também foram convidados a participar, tirando fotografias com as estátuas ou as crianças com os seus familiares.

Estas atividades de Educação Patrimonial realizadas pelo CAM, com o apoio do Museu de Mértola, tem como objetivo promover a identidade local, a consciencialização do valor do Património e da necessidade da sua preservação. Por outro lado, temos como objetivo aproximar os residentes aos núcleos museológicos, dos locais de interesse patrimonial e do conhecimento do património no seu sentido mais lato e abrangente, e dar a conhecer o património local incutindo um sentimento de pertença. Para isso, a forma que nos parece mais assertiva é trabalhar com todas as faixas etárias. No entanto, o trabalho com as crianças afigurar-se-nos como a melhor maneira de implicar as novas gerações nos processos de conservação, salvaguarda e divulgação do seu Património, desde tenra idade.

Todas estas atividades realizadas, pelo CAM em parceria com o Museu de Mértola, são acompanhadas da produção de recursos didáticos, fruto da experiência continuada e da necessidade de materiais que facilitem a aprendizagem: "Caderno do Pequeno Arqueólogo”, Jogos de mesa, Jogos de memória, Puzzles (Figura 8), Cartas, pinturas, entre outros (Palma e Rodrigues, 2019, p.122). Tanto para os mais pequenos como para o público geral, como é o caso da publicação de 2016, "Mértola da escavação arqueológica ao Museu” (Palma e Rodrigues, 2016). Esta publicação, através de uma linguagem simples explica todo o processo, desde o momento da escavação até à exposição no Museu, para além de mostrar algumas das principais descobertas, assim como o seu processo de investigação, conservação, valorização e divulgação, os quais são as principais chaves do projeto "Mértola Vila Museu" que cumpriu, em 2018, quarenta anos de trabalho em prol do património.

Com a restante comunidade trabalhamos de diversas formas, através de conferências, sessões de conversas, publicações, exposições e com o programa que foi implementado em 2017 e 2018, "Arqueologia para Todos" - uma atividade de ciência para todos, que contempla diversas ações como conferências, exposições, conversas temáticas, ateliers e escavações arqueológicas. 


\section{CONSIDERAÇÕES FINAIS}

Com estas atividades e estes recursos pretendemos criar e transmitir às diferentes gerações o valor do património de Mértola e a importância da sua preservação e divulgação, criando laços identitários e um forte sentimento de pertença e sentido de missão na sua transmissão para as gerações futuras. Convictos que a valorização e divulgação do património é o caminho certo, pretendemos continuar com as nossas atividades anuais com o Agrupamento de Escolas de Mértola, com os professores, educadores, instituições locais e comunidade em geral. No entanto, muito mais se pode fazer no âmbito da educação para o património. A divulgação e sensibilização devem ser práticas contínuas, dinâmicas, com resultados visíveis na formação pessoal e no sentido de grupo. No caso de Mértola, o património arqueológico tem um papel fundamental devido à sua presença no dia-a-dia da população. Trabalhamos para que haja uma arqueologia cidadã, participativa e que não esteja longe dos assuntos importantes desta comunidade, pois o património é seu, é testemunho das suas raízes e cultura. Desta forma entendemos que a Educação Patrimonial não é mais do que uma Educação para a Cidadania, que deve ser ativa e que se deve incutir desde tenra idade nos membros da comunidade local. A didática e as aprendizagens realizadas no âmbito do Projeto Mértola Vila $\mathrm{Mu}$ seu, desenvolvidas pelo CAM e Museu de Mértola, privilegiam as experiências, o contacto direto com o património, são facilitadores e promotores de novas aprendizagens no domínio da História Local.

\section{BIBLIOGRAFIA}

CUSTÓDIO, Jorge (200o) - Educação patrimonial. Revista da Associação Portuguesa dos Municípios com Centro Histórico, 1 (4), 10-11.

GÓMEZ MARTÍNEZ, Susana (2016) - Mértola, Vila Museu. Un proyecto cultural de desarrollo. In VAQUERIZO, D.; RUIZ, A.B.; DELGADO, M. (Eds.) RESCATE. Del registro estratigráfico a la sociedad del conocimiento: el patrimonio arqueológico como agente de desarrollo sostenible. Córdoba: Editorial Universidad de Córdoba, 2016. ISBN 978-84-9927-282-5. Tomo 1, p. 269-286.

GÓMEZ MARTÍNEZ, Susana; RAFAEL, Lígia; TORRES, Cláudio (2016) - Mértola Vila Museu. Um projecto arqueológico de desenvolvimento integrado. Revista Arqueologia Pública. [Em linha] Campinas: LAP/NEPAM/UNICAMP. Vol.1o, nํㅜ 3, pp. 55-8o. DOI: http://dx.doi.org/10.20396/ rap.v1oi3.8645842. Disponível em http:// periodicos. sbu. unicamp.br/ojs/index.php/rap/article/view/8645842/ 14463. ISSN: 2237-8294.

PALMA, Maria de Fátima (2019) - Campanhas de Escavações em Mértola, uma experiência de Arqueologia participativa. Agenda Cultural de Mértola, Outubro, Novembro e Dezembro. Mértola, Câmara Municipal de Mértola, pp. 33-34.

PALMA, Maria de Fátima; RODRIGUES, Clara (coord.) (2016) - Mértola: da escavação arqueológica ao museu. Mértola: Campo Arqueológico de Mértola. ISBN 978-972-9375 $-50-7$.

PALMA, Maria de Fátima; RODRIGUES, Clara (2019) - Atividades de Educação Patrimonial - Campo Arqueológico de Mértola, Revista Al-Madan online, №22, Tomo 4, pp.12O122. ISSN2182-7265. Disponível em: https://issuu.com/ almadan/docs/al-madanonline22_4.

PALMA, Maria de Fátima; LOPES, Virgílio (2019) - Campo Arqueológico e Museu de Mértola experiências partilhadas. In BUGALHÃO, Jacinta - Gestão Publica do Património Arqueológico, Revista Al-Madan, II série №22, pp. 55. ISSN o871-066X.

RAFAEL, Lígia (2010) - Os trinta anos do Projecto Mértola Vila Museu [Texto policopiado]: balanço e perspectivas. Évora. Dissertação de mestrado apresentada ao Departamento de História da Universidade de Évora.

RAFAEL, Lígia; PALMA, Maria de Fátima (2013) - Os museus como espaços de sociabilidade: as experiências educativas do museu de Mértola. Simpósio Internacional Arte, Património e Museus. Disponível em www: http://hdl. handle.net/10400.26/4427

TORRES, Cláudio (1989) -Arqueologia, história local e desenvolvimento. Lisboa, Instituto Nacional de Investigação Científica, Centro de Estudos de Etnologia.

TORRES, Cláudio (1993) - Dignidad regional y desarrollo. In Jornadas andaluzas sobre: la función de la cultura en el desarrollo local. Córdoba: Diputación Provincial de Córdoba, 1993, pp. 15-18.

Nota: Agradecimento a Maria João Martins pela tradução do resumo a inglês. 


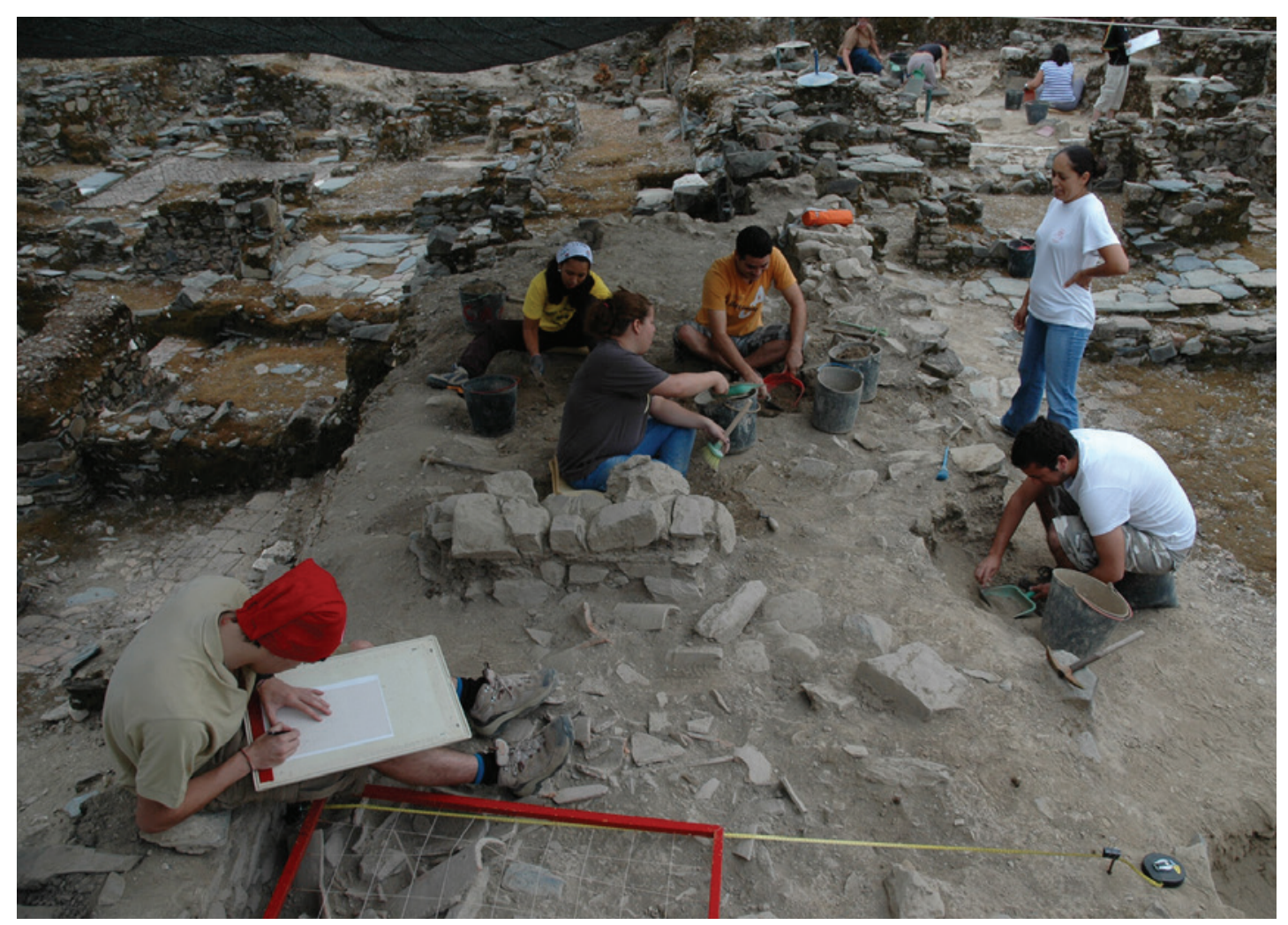

Figura 1 - Campanhas de escavações arqueológicas de verão.

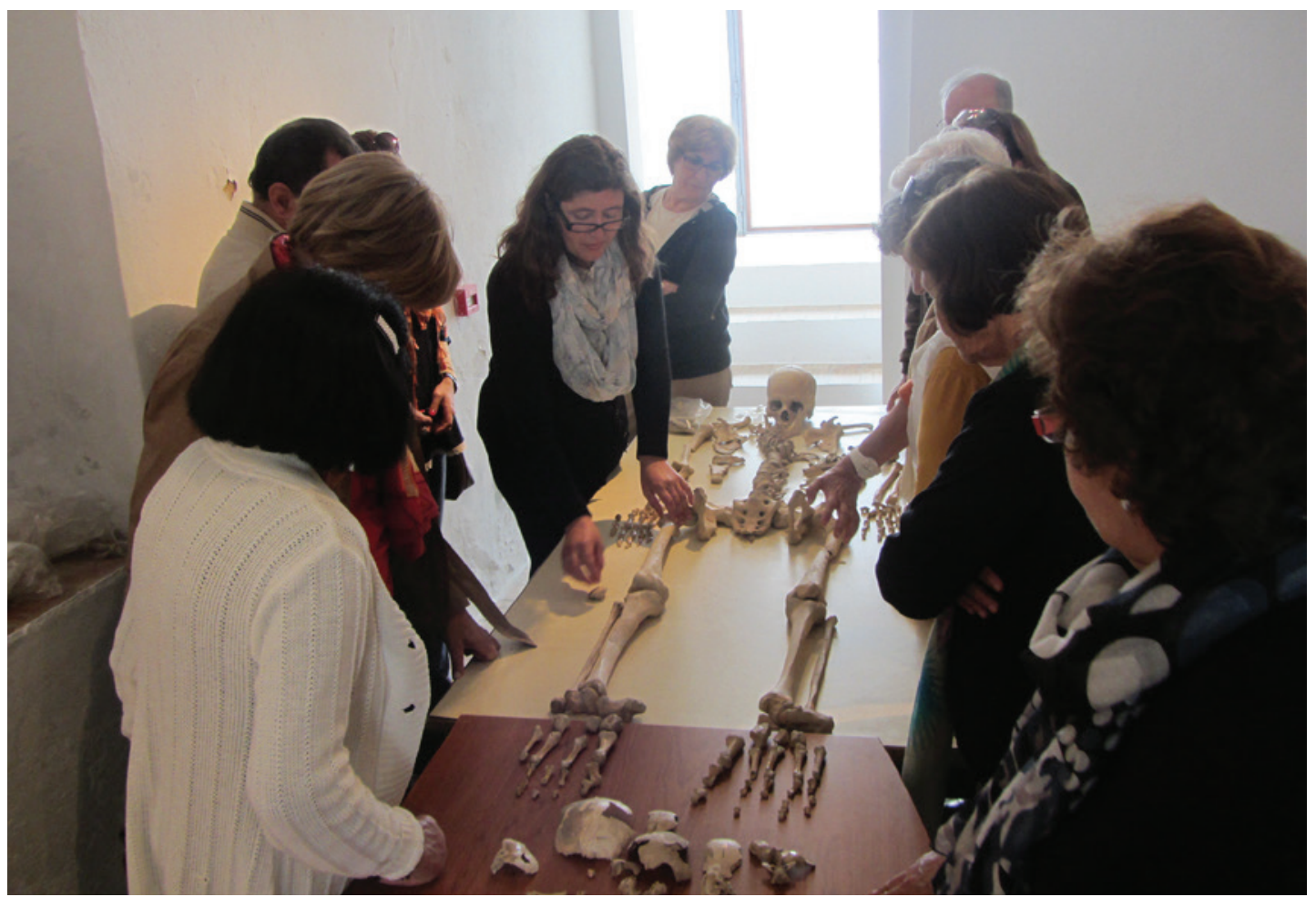

Figura 2 - Atividade de Antropologia Física com a Universidade Sénior - Pólo de Mértola. 


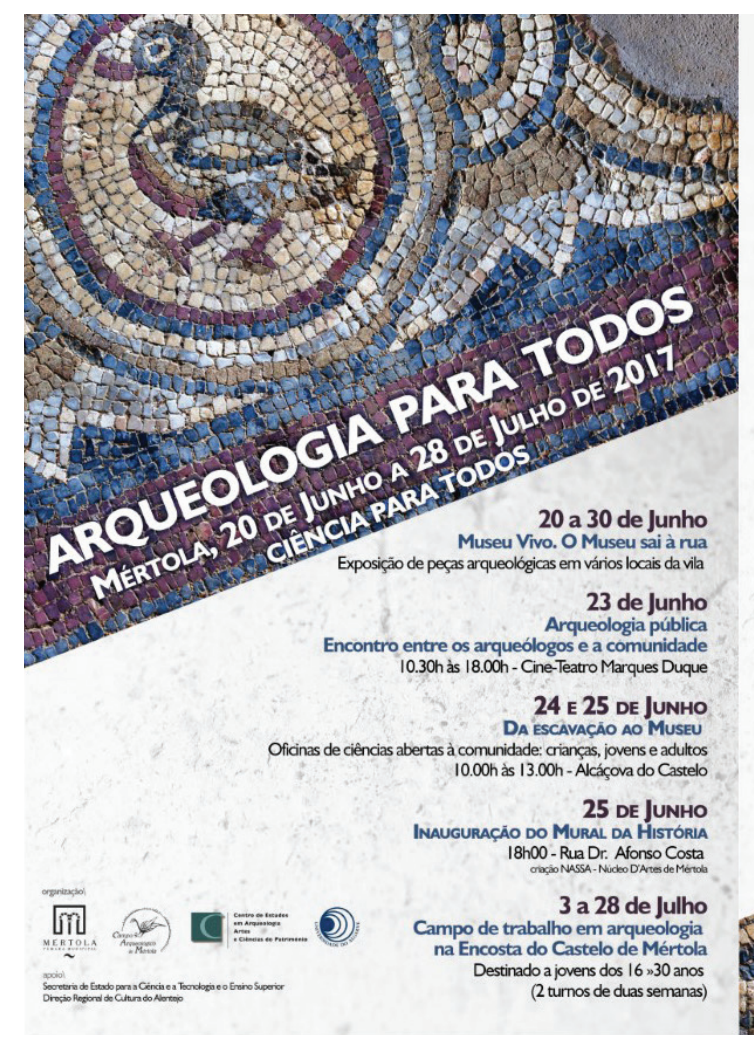

O Património Arqueológico constitui uma parte muito importante da Herança Cultural que a todos pertence. É uma Herança feita de camadas sucessivas de História, por vezes oculta ao nosso olhar, mas que com a ajuda da ciência podemos trazer à luz com rigor e paciência. Também é uma Herança frágil. Para que continue a ser um Legado para o futuro, todos devemos contribuir para protegê-la

Para proteger temos primeiro que conhecer. Por isso, convidamos todos os cidadãos a participar na descoberta científica do nosso passado e a colaborar na sua preservação.

Mértola é uma vila milenar. Aqui a arqueologia está presente em cada canto e oferece-nos imensas possibilidades de descobrir vestígios e marcas deixadas pelas gentes que habitaram esta terra ao longo de muitas centenas de anos. Podem ser edificios monumentais, objetos belos e por vezes exóticos ou, simplesmente, a marca deixada pelos gestos quotidianios das pessoas que aqui viveram.

Neste verão, propomos à população várias atividades para conhecer e participar na Arqueologia:

Venham a descobrir o nosso Património!

Figura 3 - Cartaz divulgativo Arqueologia Para Todos - 2017.

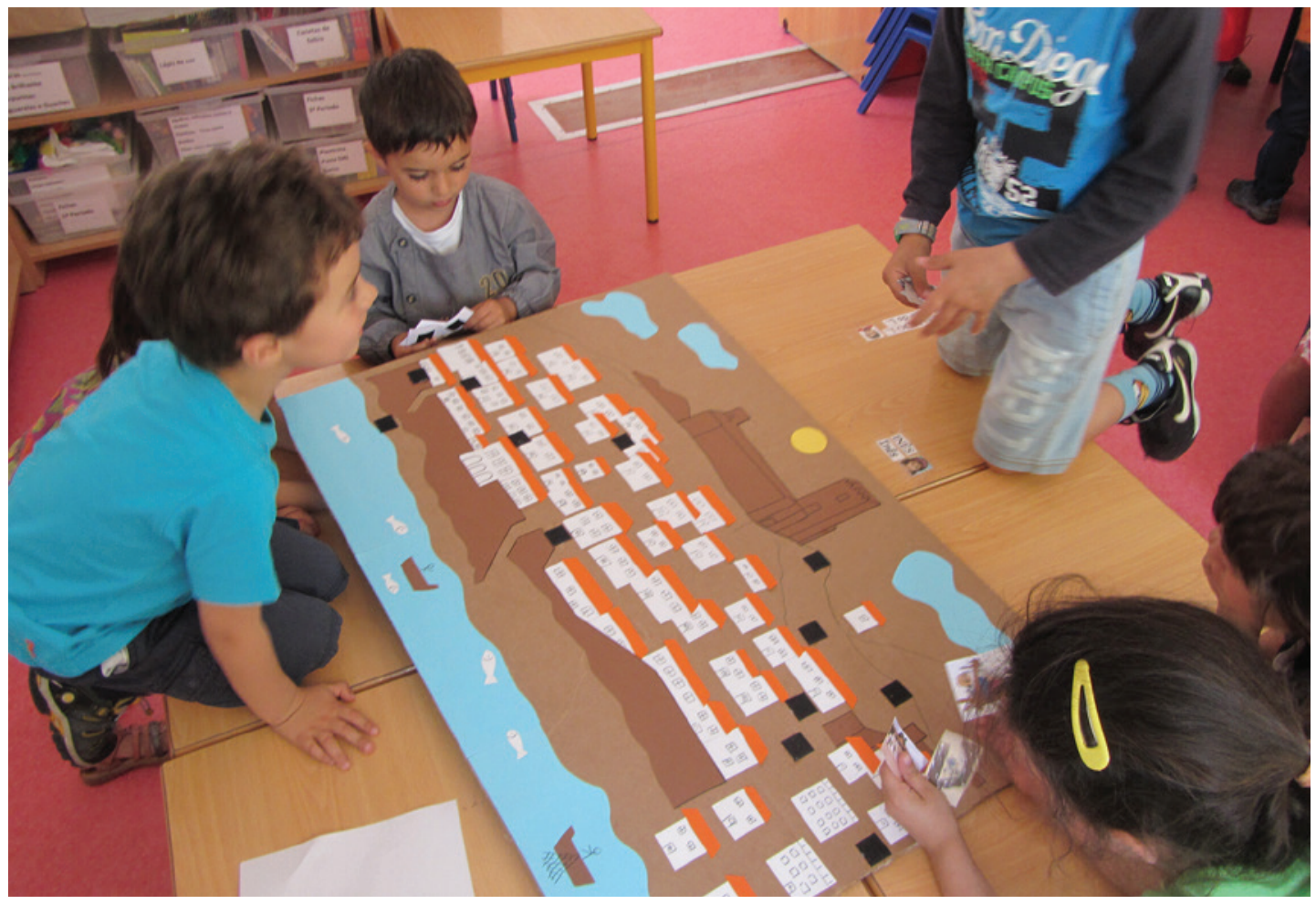

Figura 4 - Dinamização da Atividade "Património da minha Vila”. 


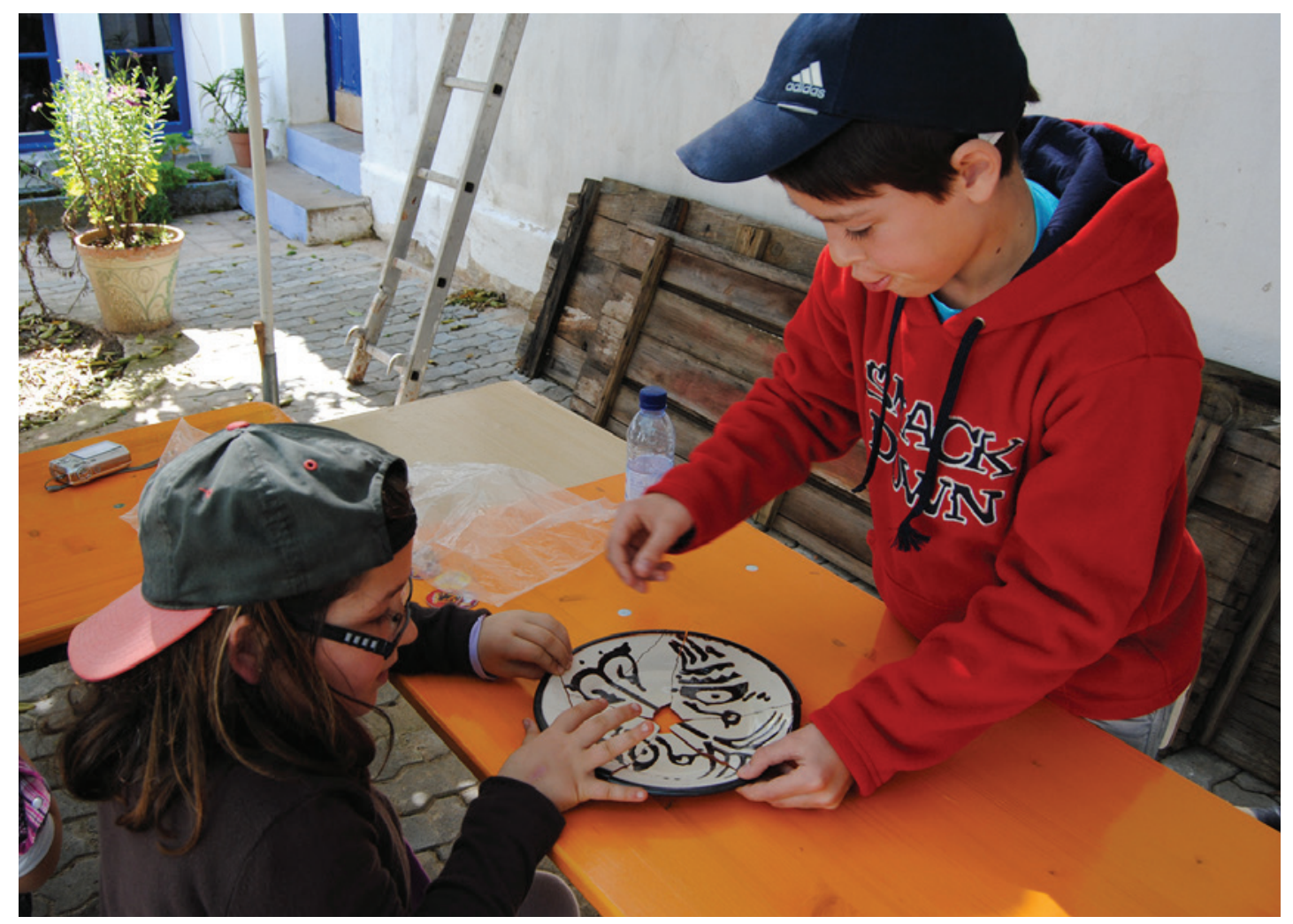

Figura 5 - Dinamização da Atividade “Conservação e restauro de cerâmica arqueológica”.

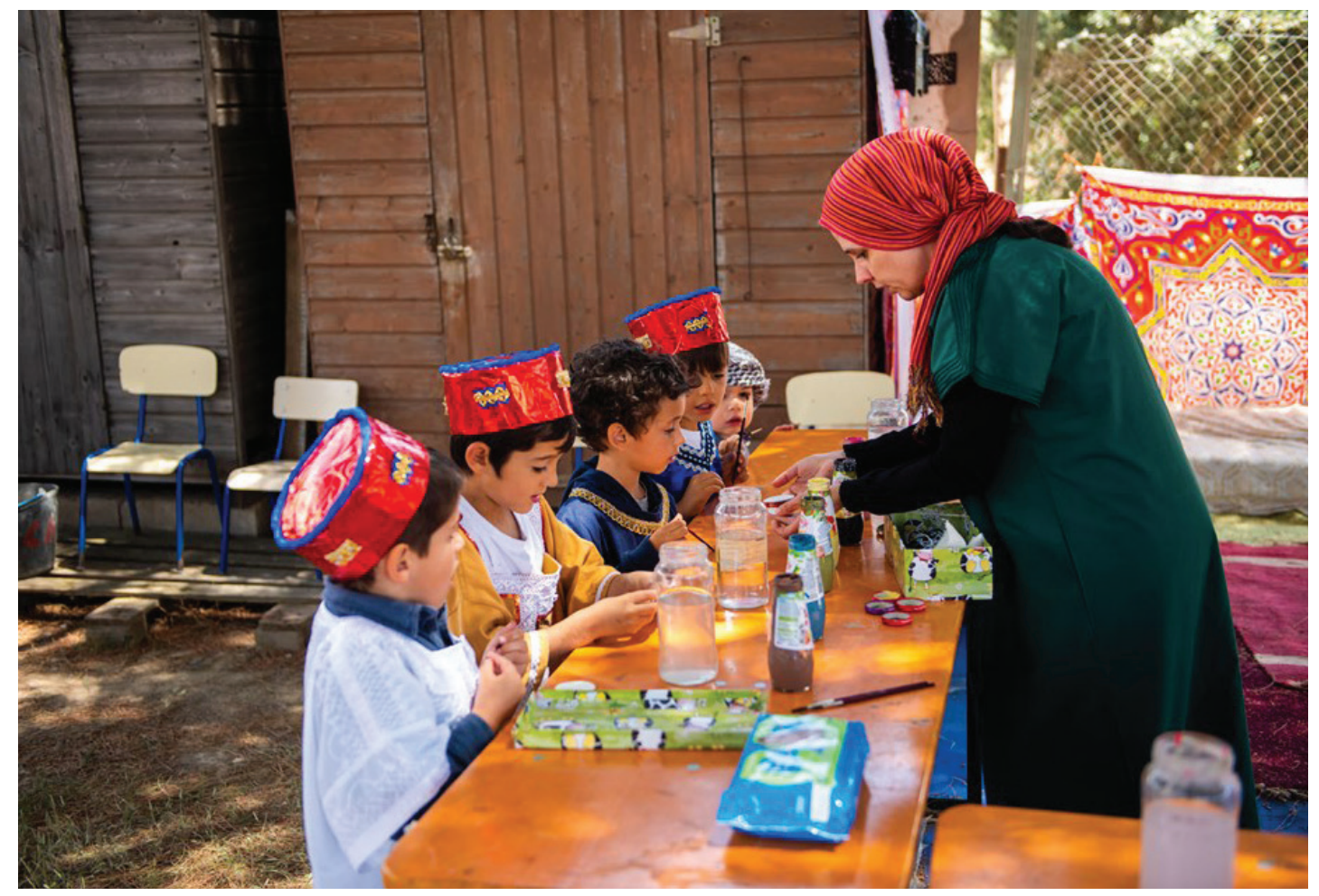

Figura 6 - "Os árabes de Martulah", dinamização de atividade com todas as Salas do Pré-Escolar e 1ํㅡㄹㅣo do Agrupamento de Escolas - Festival Islâmico de Mértola - 2019. 


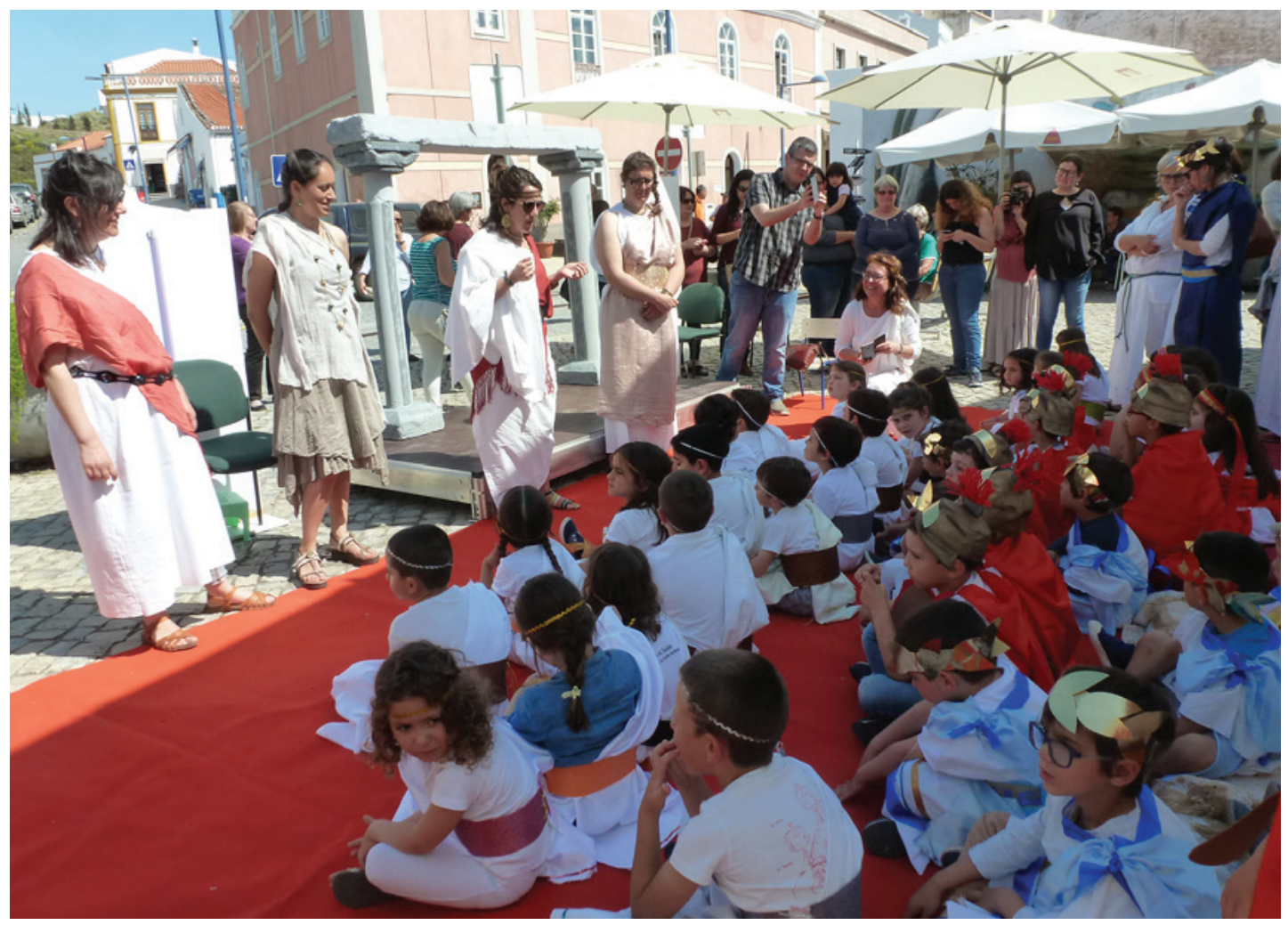

Figura 7 - Dinamização da Atividade "Os romanos de Myrtilis"com a participação das Salas do Pré-Escolar de Mértola-2018.

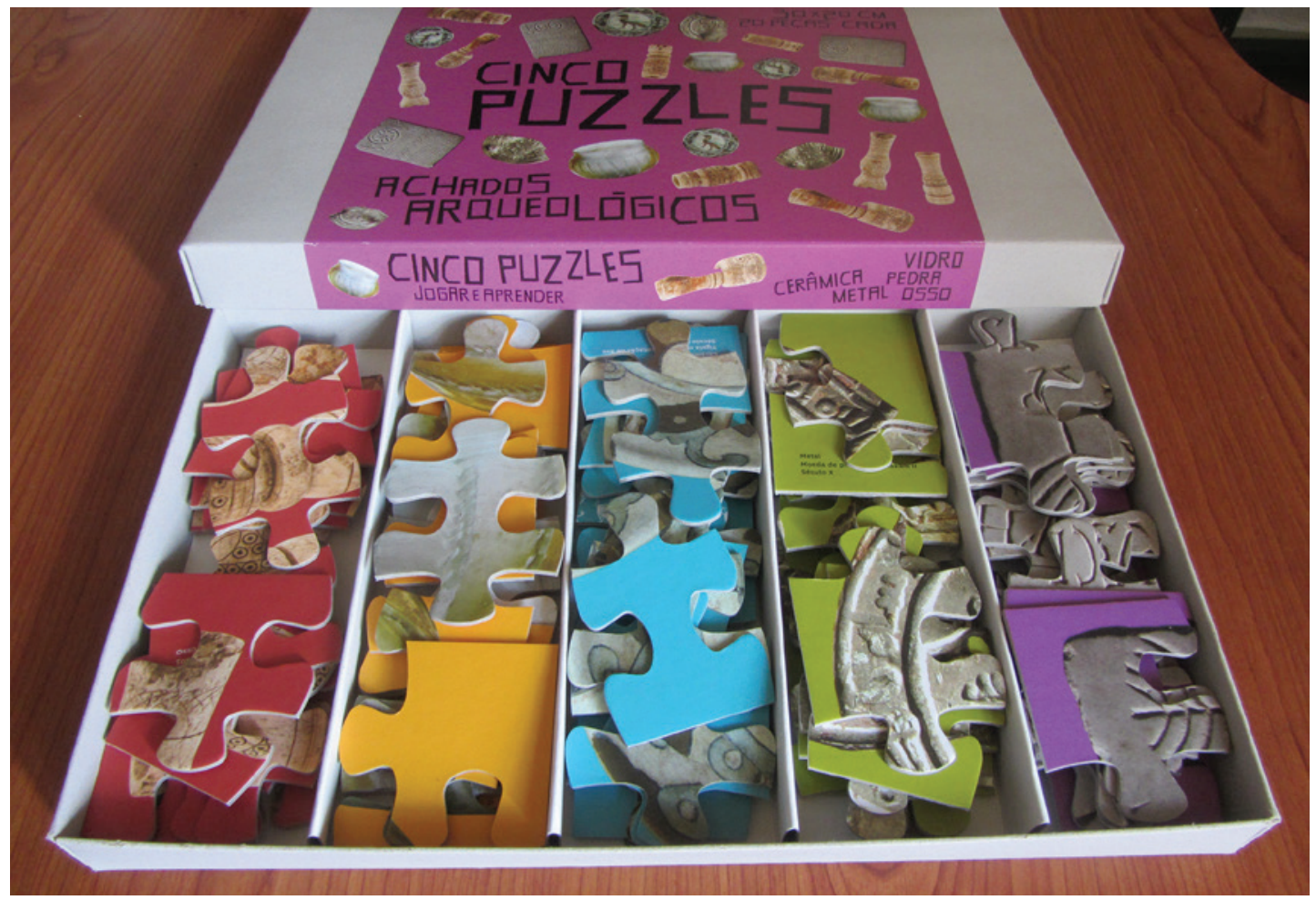

Figura 8 - Recursos Didáticos: Caixa com 5 puzzles refentes a diferentes materiais encontrados na escavação. 


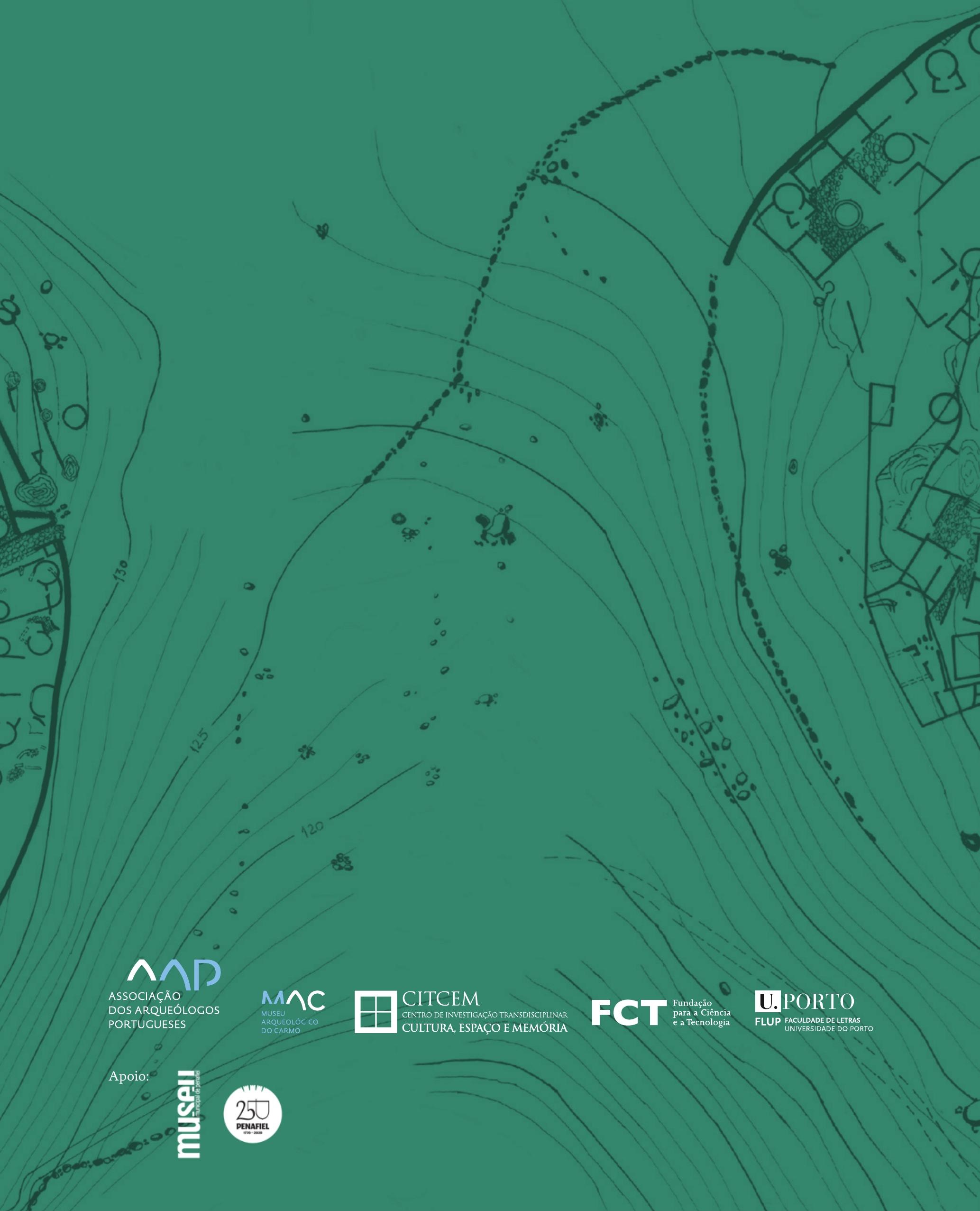

